\title{
Proteomics Approaches towards Early Detection and Diagnosis of Cancer
}

\section{Abdelkrim Khadir and Ali Tiss*}

Biochemistry \& Molecular Biology Unit, Dasman Diabetes Institute, Kuwait

\begin{abstract}
Early stage detection of cancer is the key to provide a better outcome for therapeutic intervention. Most routine screening and diagnosis tools for cancer lack sufficient sensitivity and/or specificity and sometimes they are invasive. Proteomic technologies hold recently great promise in the search of new clinical biomarkers for the early detection and diagnosis of cancer as well as the discovery of new therapeutic targets from accessible bio-specimens. They also have the potential for contributing to the better understanding of cancer biology and helping in making the right therapeutic decisions for patients. Whereas some proteomic approaches, such as the ones used for identifying proteins and analyzing their interaction and function, are well established, others, such as protein expression profiling for biomarker discovery and validation, are still suffering from robustness and reproducibility issues before being able to have their clinical applications in cancer.

In this perspective, we attempt here to first, briefly summarize the various mass spectrometry (MS)-based proteomic approaches and techniques used in cancer studies, then we discuss the complexity and the critical steps in handling and processing biological samples, and finally, we focus on the most promising strategies and techniques which may shorten the way from bench to bedside in cancer proteomics. These include; directed proteomics approaches, such as targeting disease tissues and subcellular compartments, analysis of post-translational modifications of selected subsets of proteins, selective reaction monitoring quantitation, and 'omics' integration strategy. MS-based imaging of tissue biopsies and Surface Plasmon Resonance techniques coupled to MS will be also discussed as they emerged recently as promising applications for biomarker discovery and validation.
\end{abstract}

Keywords: Cancer; Proteomics; Mass spectrometry; Biomarker

Abbreviation: 1D-PAGE: One Dimensional Polyacrylamide Gel Electrophoresis; 2D-PAGE: Two Dimensional Polyacrylamide Gel Electrophoresis; 2D-DIGE: Two Dimensional Differential In-Gel Electrophoresis; AFP: Alpha-Fetoprotein; CA19-9: Carbohydrate Antigen 19-9; CA-125: Cancer Antigen 125; CEA: Carcino-Embryonic Antigen; ESI: Electrospray Ionization; HCC: Hepato-Cellular Carcinoma; ICAT: Isotope-Coded Affinity Tags; iTRAQ: Isobaric Tags for Relative and Absolute Quantification; LC: Liquid Chromatography; MALDI-MSI: MALDI MS Imaging; MALDI-TOF: Matrix Assisted Laser Desorption/Ionization-Time of Flight; MS: Mass Spectrometry; MudPIT: Multidimensional Protein Identification Technology; PSA: Prostate-Specific Antigen; PTMs: Post-Translation Modifications; SELDI-TOF: Surface Enhanced Laser Desorption/Ionization-Time of Flight; SILAC: Stable Isotope Labeling by Amino Acids in Cell Culture; SPR: Surface Plasmon Resonance

\section{Introduction}

Genome sequencing and analysis have produced a wealth of information during the last two decades, including the full genome sequence. The ultimate following step was to look at proteins; the workhorse biomolecules that are translated from genes and functionally govern cellular processes and control disease progress and malignancy. Due to various cellular mechanisms including alternative splicing and post-translational modifications of proteins (e.g., phosphorylation, glycosylation, acetylation, and proteolytic cleavage) it is estimated that the human proteome comprises more than 500,000 proteins $[1,2]$ in comparison with about 22,000 protein-coding genes [3]. In addition, proteins dynamic is more complex than in genes, due to proteins various localizations through the cell, half-lives, interconnectivity into complexes and signaling pathways, and also response to stimuli such as disease and treatment [4]. Moreover, it is now well established that changes in levels or abundance of genes and their transcripts do not always correlate with protein abundance $[5,6]$. Therefore, cancer can now be considered as a proteomic disease and more linked to the post-transcriptional steps [7] even there is still a partial contribution of genetic background to the predisposition and development of this disease.

Available protein-based screening and diagnosis tools for cancer are mostly based measurement of serum markers, such as Carcino Embryonic Antigen (CEA) for colorectal cancer, Prostate-Specific Antigen (PSA) for prostate cancer, carbohydrate antigen 19-9 (CA199) for pancreatic cancer, Alpha-Fetoprotein (AFP) for Hepato Cellular Carcinoma (HCC), and Cancer Antigen 125 (CA-125) for ovarian cancer. These markers lack sufficient sensitivity and/or specificity for early detection reflected by high false-negative and/or high falsepositive results [8]. Moreover, lung and breast cancers, most common cancers, do not even have an established markers with clinical utility for screening [9].

The poor sensitivity/specificity can be partially explained by the non-specificity of these markers for cancer as several of them are also produced by non-tumor tissues or under benign conditions. This is underpinned by the fact less than a third of men referred for prostate biopsy on the basis of increased blood levels of PSA have prostate cancer [10]. Another example is the protein CA-125 where its blood

*Corresponding author: Ali Tiss, Proteomics Lab., Biochemistry \& Molecular Biology Unit, Dasman Diabetes Institute, PO Box 1180, Dasman, 15462, Kuwait, Tel: +965 22242999 (ext: 3553); E-mail: ali.tiss@dasmandinstitute.org

Received March 20, 2013; Accepted April 26, 2013; Published May 10, 2013

Citation: Khadir A, Tiss A (2013) Proteomics Approaches towards Early Detection and Diagnosis of Cancer. J Carcinogene Mutagene S14: 002. doi:10.4172/21572518.S14-002

Copyright: ( 2013 Khadir A, et al. This is an open-access article distributed under the terms of the Creative Commons Attribution License, which permits unrestricted use, distribution, and reproduction in any medium, provided the original author and source are credited. 
level is elevated in only about half of women having early-stage ovarian cancer $[11,12]$. CA-125 also has low specificity since benign conditions, such as endometriosis and pregnancy, can elevate CA-125 levels $[13,14]$. AFP itself has abnormal expression levels in only two-thirds of HCC patients [15]. The above mentioned facts highlight the urgent, yet unmet, need for the discovery of novel but sensitive and accurate tumor markers for cancer screening, diagnosis, and prognosis as well as fostering translational research in oncology to move from bench to bedside.

On the other hand, the number of new protein biomarkers achieving FDA-approval has trended downwards for the last decade as three or less new markers are being approved per year including all diseases $[4,16]$. For cancer and till recently, only nine FDA-approved, blood-based cancer markers are available; most of them are used to monitor treatment [17]. This disappointing trend suggests that conventional approaches have reached their contribution limit and that there an urgent need to develop and implement new approaches to discover and translate new biomarkers to the clinical use [18].

Altogether, these elements make the proteome and proteomics of a great interest both to researchers and clinicians, in particular for complex diseases such as cancer. In addition, the possibility to systematically and simultaneously identify and quantify large number of proteins obviously positions proteomics on the forefront to understand cancer biology and to develop promising biomarkers and drug targets for the disease.

Proteome analysis principally relies on MS though other approaches are available such as microarrays and antibody panels. MS-based proteomics, after its infancy stage, starts to mature through clear developments both in technologies and in experimental strategies [19]. Indeed, after the hype which followed the first landmark studies published a decade ago and claiming the discovery of new blood markers with both high specificity and sensitivity for example for ovarian cancer [20], joint efforts between clinicians, scientists and technologists helped to address many issues and emerged a reasonable hope from these approaches.

In this review we are not aiming to summarize the numerous studies and results linked to onco-proteomics but rather a brief description of the various strategies and MS-based approaches used with a focus on the most promising ones which may lead the next development steps and implementation of proteomics in the field of cancer detection and diagnosis.

\section{Proteomic Approaches for Cancer Studies}

The discovery and clinical application of novel tumor markers for cancer screening, diagnosis, and prognosis are actually key focus areas of translational research in oncology and represent urgent needs in the fight against cancer [8].

MS-based proteomics can be used for early discovery steps of biomarkers and their validation but also for clinical diagnosis and prognosis as an endpoint clinical assay (Figure 1). Although conventional proteomics has become a key approach in biomarker discovery and validation, some of the most recent MS technologies have not yet been introduced to clinical application due to their complexity or their high cost [21].

In practice and regardless the various available combinations of MS machines, the most commonly used platforms for the analysis of protein expression (identification and quantitation) are Matrix Assisted Laser Desorption/Ionization (MALDI) and Surface Enhanced Laser Desorption/Ionization (SELDI) combined with Time of flight (TOF) MS and Electrospray Ionization (ESI) MS combined with Liquid Chromatography (LC-ESI-MS, LC-MS/MS).

\section{Biomarker discovery}

During the last few years, and due to the development of innovative MS-based proteomic technologies and strategies to deeply investigate the oncoproteome, large lists of potential biomarkers were generated although most of them are still at the level of discovery and/or validation [22]. In addition, the high throughput capacity in MS-based proteomic approaches for biomarker discovery and validation is seen to be a key element in the integration of the various oncogenomic and oncoproteomic data to fully comprehend cancer biology in particular with the growing array of genes and proteins data available in compiled and curated databases [23].

Indeed, large efforts were made to deeply investigate the oncoproteome using various human biospecimens including cell lines, tissue biopsies, blood components (serum, plasma, and mononuclear cells), urine, saliva, and cerebrospinal fluid (for reviews see for example: $[8,9,12,18,21,24])$.

In MS-based proteomics research for biomarker discovery, there are two main approaches currently used in cancer which are: Protein identification and pattern recognition (Figure 1). Both approaches require high-capacity computing and bioinformatics systems to process the enormous amount of data that are produced by proteomic studies. Furthermore, confidence in the identified biomarker signatures requires to be reproduced in different populations and by different laboratories. The discussion of the outcomes of the cancer proteomic studies is beyond the scope of this review, some of those studies will be, however, briefly summarized with each MS-based proteomic technology in the next section of this review.

Protein identification and quantification: Identification and quantitation of proteins and peptides by MS are usually carried out using one of the two following strategies: the first is called 'bottom-up' approach which refers to the reconstruction of the protein sequence, and thus its identification and quantitation, from the sequences of its peptides fragments after proteolytic digestion, and by analyzing the peptides mass spectra using appropriate databases. The second is the 'top-down' approach referring to the identification of a protein directly from its full sequence without enzymatic digestion. Hence, the biomarker discovery approach can be comprehensive, to enumerate, identify and quantitate as many protein components as possible from a biological sample on a data-based manner. On the other hand, protein identification and quantitation can be also focused on small set of candidate proteins issued for example from a co-immuno-purification, or even from shortlisted proteins linked to specific signaling pathway or drug target that differentiates between diseased and control subject phenotypes, in a hypothesis-based manner [25]. Identification of protein targets will immediately facilitate their quantification and validation as well as evaluating their potential clinical value for further development [26]. Protein targets that are identified with MS could also be further characterized to understand their functional role in cancer biology. Key signaling hubs of pathways involved in carcinogenesis are obviously potential molecular targets for therapeutics, and inhibitor drugs against such proteins $[27,28]$ and are good examples of hypothesis-based approach in protein identification. 
Citation: Khadir A, Tiss A (2013) Proteomics Approaches towards Early Detection and Diagnosis of Cancer. J Carcinogene Mutagene S14: 002. doi:10.4172/2157-2518.S14-002

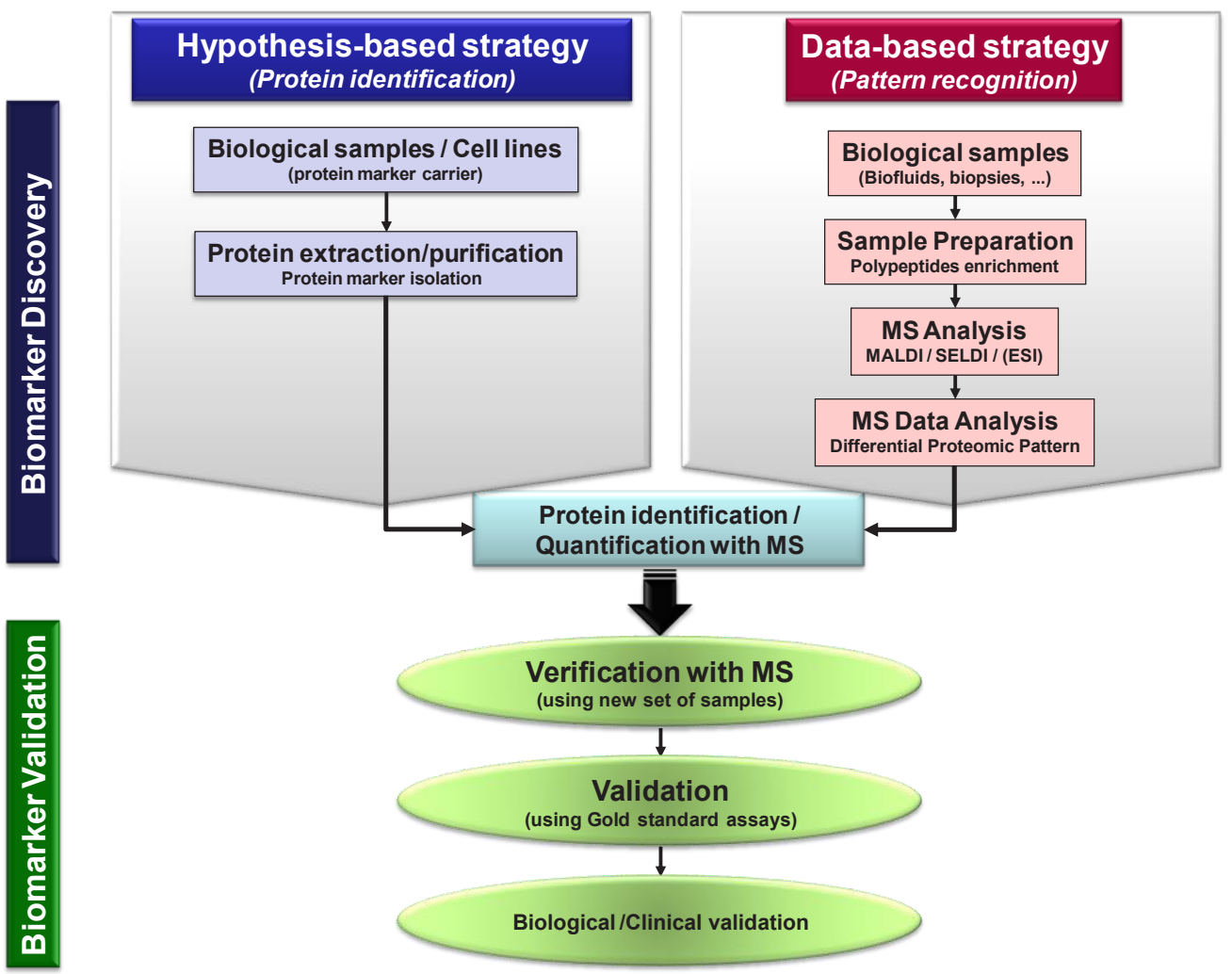

Figure 1: Workflow diagram of MS-based proteomics strategies and platforms used in cancer biomarker discovery and validation.

In practice, the identification of proteins using MS is nowadays well established and a straightforward proteomic task even though some purification/enrichment steps might be needed. This will developed in the section about MS platforms.

Pattern recognition: As mentioned above, cancer is characterized by the heterogeneity of its pathogenesis reflected by the multiple dysregulated proteins and cellular pathways involved in the initiation and progression of the disease. In addition, most proteins produced by tumor cells are not unique and also produced by non-cancerous cells [29]. Hence, it is now largely accepted that a single biomarker is less likely to have sufficient sensitivity and/or specificity for populationbased screening and early detection of cancer. Instead, the discovery of a panel of biomarker called "protein signatures" or "protein pattern" comprising several proteins is thought to provide higher sensitivity and specificity [30-33]. In support to this vision, many recent proteomic studies effectively reported that protein panels are more accurate tools for detecting cancer than individual proteins [34-39].

In this pattern recognition approach, MS combined with adequate bioinformatics tools are used to measure the mass and relative quantity of all proteins or peptides in biological sample without proteolysis or deep fractionation. By comparing profiles (protein signatures) between samples taken from patients with those taken for their matched healthy controls, a list of differentially expressed proteins is generated and used for further validation (Figure 1). Independent identification of those proteins is consequently carried out on MALDI-TOF-MS/MS or LCMS/MS or even with gold standard assays to rollout the likelihood that differences in protein signatures observed between those biological samples are due to experimental bias. This approach needs however, large set of samples and good experimental reproducibility to overcome the inter-individual physiological variability. The OVA1 test, an In Vitro Diagnostic Multivariate Index Assay (IVDMIA) constituted of a panel of protein markers recently approved by the US FDA, represents the first clinical application of this protein signature approach [40]. This test is used to assess ovarian cancer risk in women diagnosed with ovarian tumor prior to a planned surgery.

\section{Clinical diagnostics}

Even though MS-based proteomic approaches are powerful discovery tools, MS is currently used in clinical settings only for few applications. This is due, at least partially, to its complexity and its low time-cost efficacy when compared to other well established standard techniques such as immunoassays or enzymatic tests [21]. Nevertheless, MS has found its application in clinical analysis longtime ago for example in the neonatal screening programs for inborn errors of metabolism, in particular for phenylketonuria which is now established in several countries [41-43]. More recent implementation of MS-based proteomics in clinical settings are the above-mentioned OVA1 test for clinical diagnosis of ovarian cancer [40] and also the IVD MALDI biotyper MS for identification of microorganism species in clinical microbiology labs [44]. This last test is a MALDI-TOF MS based benchtop platform for rapidly identifying bacteria and yeasts using a database of over 3,900 strains from about 2,000 well-characterized microbial species. Starting from a cultured colony, identification is performed by matching the measured protein fingerprint against the proprietary Biotyper database. Using this system, 30 to 60 strain identifications can be performed every hour with a reasonable low false positive rates, low operational costs, and low technical barriers for new operators $[44,45]$.

Altogether, these recent developments are fostering the transition 
of MS from a discovery tool to a validation and diagnostic tool in clinical laboratory settings for the foreseen future [21,46,47]. For other applications, and to overcome the limiting issues hampering the large introduction of MS applications into the clinics, MS does not require to be physically available in the clinical lab and could be used for specific needs within an appropriated research lab [21].

\section{MS-based Proteomic Platforms for Cancer Studies}

\section{Sample preparation and protein enrichment}

Considerations for biological samples: A considerable progress has been achieved during the last years in proteomic technologies and strategies which enabled deciphering many biological and pathophysiological mechanisms linked to proteins and their genes. The successful transition of these technologies from research tools to clinical diagnostic/screening platforms is however still challenged by some basic issues linked to the human physiology and sample quality. Indeed, the complex nature and instability of the human clinical samples during their collection and analysis, due to the degradation of their quality and content linked to the presence of enzymes proteins, make the integrity of those samples during the whole processing steps a key to any analysis of their content $[48,49]$. The large dynamic range in protein concentration and the presence of different sates of proteins (various isoforms and PTMs) are other hurdles for proteomics to overcome.

For example and despite the development of standardized experimental protocols for enrichment, separation, and quantification of proteins, there is still gaps in the expected reproducibility of proteomic analysis between different laboratories mainly due to the change and degradation of protein samples during the pre-analytical (sample collection, handling and storage) and analytical steps [50]. As a consequence, an extra effort was undertaken during the last few years to overcome these issues to ensure acceptable reproducibility and avoid experimental bias. Several groups have reported recently about the potential confounding effects of pre-analytical and analytical steps, aside with various recommendations addressing best practices for specimen handling with more stringent precautions to maintain the integrity of proteins and ensuring accuracy and reproducibility of proteomic results $[48,49,51,52]$.

These recommendations include detailed SOPs starting from the experimental design such as good matching between cases and controls (gender, age, other morbidities, etc), minimum required number of samples, the use of different sets of samples for discovery and verification/validation steps to avoid systematic bias and reduce the false discovery rates of disease markers [53]. They also include reporting as much information as possible about the way the biological samples were collected, handled and pre-processed since these preanalytical steps are often carried out in a clinical setup and not under the control of the investigators studying disease markers. It is also frequent that the sample analysis is performed awhile after its storage and thus, it is important to have detailed reports the storage conditions.

Once all the optimal conditions for sample collection and handling are established and the appropriate proteomic technologies are selected, there is also the need to share biospecimen resources between independent research groups and institutions for the biomarker discovery and/or the validation steps. Finally, cohort and time-serial samples collected before the onset of the cancer are particularly useful to foster discovering and validating cancer-specific biomarkers for early detection and follow-up of the disease.
In the following section, we summarize only the two most common techniques used for protein separation, many other techniques are available but they are beyond the scope of this review.

Gels electrophoresis: Before being analyzed by MS, biological samples usually need to some extend preliminary separation, enrichment or fractionation of their protein content due to their complexity. The most common approaches for protein separation are based on protein size or their physical chemistry properties.

One of the first techniques is the one-directional polyacrylamide gel electrophoresis (1D-PAGE), where proteins from biological samples are separated based on their size by applying an electric current to a gel matrix, in which the smaller proteins move faster than the larger proteins through the gel. The resulting gel is then stained, using various reagents such as Coomassie blue dye, silver staining [54], fluorescent dyes [55] or radiolabels, and protein bands can finally be viewed and quantified for analytical or preparative purposes. 1D-PAGE technique has however a major limitation as only few tens of proteins can be clearly separated at the same time from biological which may contain hundreds to thousands different proteins. Another challenge for this technique is its low resolution as it cannot separate proteins of very similar size such us protein isoforms.

Most of these inherent limitations where however overcome later by developing and using a more complex gel-based separation method, the Two-Dimensional Gel Electrophoresis (2D-PAGE) [56]. In this technique, proteins are separated by two independent steps using two distinct properties. First, proteins are separated in a gel strip according to their isoelectric point $(\mathrm{pI})$, where the net charge of the protein is zero. The proteins are then separated in a second experiment by placing the gel strip on top of a standard Sodium Dodecyl Sulphate (SDS-PAGE), which separates the proteins according their size as in 1D-PAGE.

The 2D-PAGE technique has, however, its own limitations such as; the low throughput as only two samples at a time can be processed, the requirement of relatively large amounts of sample and the time consuming laborious protocol. As the principle of the method relies on the comparison of the spots intensity within gels obtained from different samples or subjects, the inter-gel variability represented an extra hurdle for this method. Nevertheless, this was particularly enhanced by the development of the 2D-differential in-gel electrophoresis (2D-DIGE) in 1997 [57] that allows comparison of two or three protein samples simultaneously on the same gel using different fluorescent dyes for each protein sample. Inter-gel reproducibility 2D-DIGE was further improved by including internal standards and developing advanced algorithms and software for spot alignment and quantitation between different gels.

Finally, for both 1D- and 2D-PAGE protein bands need to be cut out of the gel and digested with proteases (e.g. trypsin) before being identified and/or quantified using MS and appropriates databases. 1D- and 2D-PAGE protein separation are mostly used upstream to MALDI-TOF MS for specific enriched or differentially expressed proteins but for limited sample set due to their low throughput.

Liquid chromatography: Liquid chromatography, more precisely nano-LC coupled to tandem MS (LC-MS/MS) is now widely implemented in most proteomic platforms to identify and quantify large number (thousands) of proteins from complex biospecimens. The LC principle is based on a column packed with functionalized phase to separate components of a mixture by a variety of chemical interactions between the proteins or the peptides and the column. Proteins are usually digested before being bound to the column and 
Citation: Khadir A, Tiss A (2013) Proteomics Approaches towards Early Detection and Diagnosis of Cancer. J Carcinogene Mutagene S14: 002. doi:10.4172/2157-2518.S14-002

then eluted from it using appropriate elution gradients with flow rates of $\mathrm{nL} / \mathrm{min}$ to $\mu \mathrm{l} / \mathrm{min}$ allowing the use of smaller sample amounts and better sensitivity and resolution. Protein fractionation/separation can be also carried out on a separated LC system before being analyzed by MS system in a method called offline LC/MALDI or LC/MS (/MS).

Multidimensional LC with orthogonal separation of peptide digests coupled to ESI-MS, also called multidimensional protein identification technology (MudPIT) is an emergent strategy used in proteomics and involving two or more LC columns [21,58-61]. MudPIT allows the identification of few thousands of protein from a given sample, it has high reproducibility and works well for hydrophobic, acidic, basic, very small, very large and low-abundant proteins which are difficult to analyze by traditional separation techniques [21].

In practice, LC protein separation is mostly used hyphenated with an ESI-MS for both subset of specific enriched or large scale protein identification and quantitation, using limited sample sets due to LC low throughput.

\section{Mass spectrometry}

A mass spectrometer machine, the key element in the MS-based proteomic approach, has mainly three components: an ionization source, a mass analyzer and an ion detector (Figure 2). The two most common ion sources used in proteomics are based on Electrospray Ionization (ESI) from a liquid solution and Matrix-Assisted Laser Desorption/Ionization (MALDI) from solid crystals. The ion source produces ions from the sample such as peptides, proteins in the gas phase by the addition or loss of one or more protons in a so-called 'soft' ionization technique that still maintains sample integrity. A mass analyzer is then used to separate ions with different mass-to-charge ratios $(\mathrm{m} / \mathrm{z})$. The main ion analyzers used in proteomics are Quadrupole (Q), Time of Flight (TOF), ion traps, and Fourier Transform Ion Cyclotron (FT-ICR). The number of different ions is finally counted by the detector. Those ions and their numbers are finally presented by a signal processor (computer) as a mass spectrum with a series of spiked peaks, each representing the charged proteins/peptides or their fragments extracted from a given sample (Figure 2).

MALDI-TOF: In MALDI, proteins or peptides are mixed with a large excess of a suitable organic matrix and then spotted onto a plate. The dried mixture is then subjected to a laser pulse to generate clouds of matrix and proteins ions. The protein ions are accelerated into a vacuum tube (TOF mass analyzer) and travel through it until reaching a detector which converts the amount of ions to intensity. As ions with different masses will have different velocities, they will separately reach the detector and will be represented as a plot of distinct $\mathrm{m} / \mathrm{z}$ of ions against their respective intensity, a plot called mass spectrum. This obviously needs the machine to be calibrated in advance using known polypeptides mixture, to establish the relationship between the $\mathrm{m} / \mathrm{z}$ of the ions and their time of flight. In addition some MALDI instruments have the ability to provide partial amino acid sequence using its PostSource Decay (PSD) from ions with $\mathrm{m} / \mathrm{z}$ values of up to $4 \mathrm{kDa}$ or its InSource Dissociation (ISD) from larger ions with the advantage of being simple, having high sensitivity and higher tolerance to buffer and salt contaminants in comparison with ESI-MS.

MALDI-TOF MS is a versatile and can be used for various purposes including proteomic applications. In a first approach, proteins are extracted from a biological sample, digested with a protease (e.g. trypsin) and then analyzed with MALDI-TOF MS to generate a list of peptide masses unique to each protein and known as Peptide Mass Fingerprinting (PMF). Comparison of the generated peptide mass list with protein databases allows the identification of the digested proteins with reasonable confidence. This approach is particularly useful in the discovery of biomarkers due to the high sensitivity (down to attomol), relatively wide dynamic range (3-4 orders of magnitude) added to the ability for high-throughput screening [63]. Nevertheless, this PMF approach is useful when there are only one or few proteins at the same time.

Alternatively, and as a second approach, proteins (or peptides) can be enriched from clinical samples such as plasma or tissue biopsy

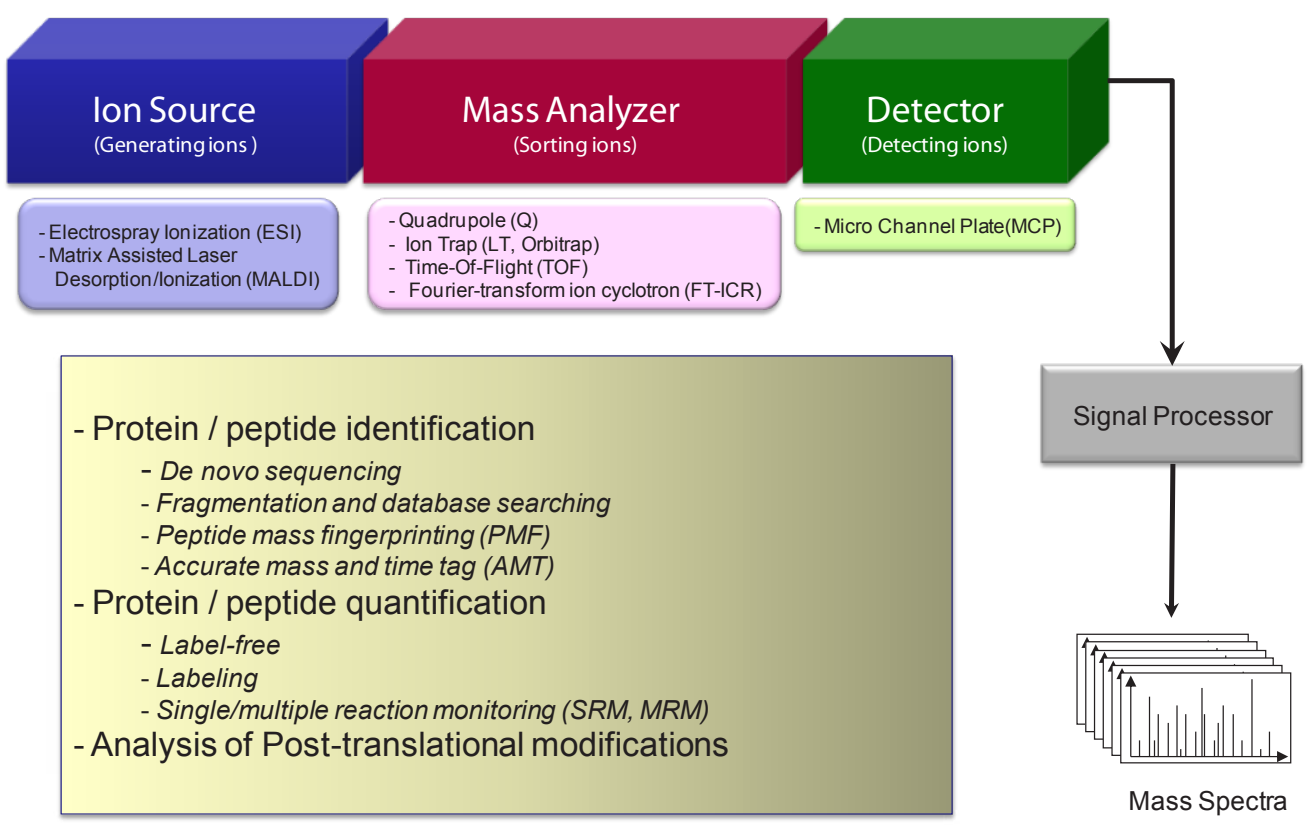

Figure 2: Simplified diagram and principles of Mass Spectrometer machines. 
Citation: Khadir A, Tiss A (2013) Proteomics Approaches towards Early Detection and Diagnosis of Cancer. J Carcinogene Mutagene S14: 002. doi:10.4172/2157-2518.S14-002

and then analyzed with MALDI-TOF MS to generate specific mass patterns of proteins intensity without relying on protein identity. These patterns can be used as a 'diagnostic fingerprint' comparing differential patterns between healthy-controls and diseased samples [39,48,49,63]. This approach is useful as a preliminary discovery step with highthroughput that allows protein expression profiling of large sample sets with reasonable costs. In more advanced MALDI-TOF MS, peptides can be fragmented to further sequence them at least partially and thus giving better confidence to the protein identification.

Due to their high throughput and versatility, MALDI-TOF MS platforms have been extensively used for human cancer detection, in particular at the level of biomarkers discovery and protein pattern signature. MALDI-TOF MS was used, in combination with variety of statistical pattern-recognition and bioinformatics tools, for example in the early detection of various cancers such as breast, ovarian, prostate, colorectal, pancreatic, melanoma and lung cancer (for detailed reviews, see for example $[21,24,64-70])$. Many protein and peptide peaks have been reported to bear significant diagnostic, prognostic or predictive value for various cancers; however, the candidate biomarkers have not yet been validated for use in clinical patient care [70]. Table 1 is summarizing a selected list of studies published using MALDI-TOF MS for cancer biomarkers discovery.

SELDI-TOF: Surface-Enhanced Laser Desorption-Ionization (SELDI) MS uses array chips (ProteinChip) with functionalized surface which selectively bind and enrich subsets of proteins. The array chips can have different physicochemical properties such as reversephase, ion exchange, immobilized metal, or antibodies affinity. As in MALDI-TOF technique, an organic matrix is then added to the bound proteins and blasted with laser beam to generate polypeptide ions. The protein array chip is often coupled to TOF-MS and bioinformatics to derive proteome patterns for the samples analyzed [71]. As other MS-based proteomic technologies, SELDI requires a low amount of samples (femto-mole range) and it has real potential for clinical applications at the bedside to analyze samples for biomarker discovery due to its high throughput and easiness of use [71-73]. The common application of SELDI-TOF MS in cancer biomarker discovery is to find signature patterns correlated to healthy and diseased phenotypes. Nevertheless, the SELDI-TOF-MS suffers from its inability to directly and accurately identify the proteins within proteome patterns, and its relatively low mass resolution which limited the use of SELDI-TOF MS [74]. Due to the high dynamic range of protein levels in serum and plasma, the ProteinChip array can be quickly saturated with highabundance proteins due to its low binding capacity [50,75], and thus pre-fractionation steps are mandatory to identify biomarkers present at low abundance.

One of the first discovery studies carried out using SELDI-TOF MS for ovarian cancer detection [20], generated a wide excitement both in the scientific community and the private sector, as their results were quickly converted into a commercially available diagnostic test (OvaCheck", Correlogic, Inc., Germantown, MD). Hence, SELDITOF MS was widely used in researches related to signature detection of cancer protein patterns [74]. This includes ovarian cancer [20,76], prostate cancer [77-79], breast cancer [80,81], lung cancer [82], colon cancer [83], and liver cancer [84]. SELDI-TOF MS was also applied for example to cancer relapse and prognosis of nasopharyngeal carcinoma $[85,86]$. More recently, the Lucid Proteomics System ${ }^{\mathrm{Tw}}$, combining SELDI-TOF MS and MALDI-TOF/TOF MS technologies has provided further hopes for biomarker discovery on a single platform with improved spectra resolution and reproducibility [87]. Table 2 is summarizing a selected list of studies published using SELDI-TOF MS for cancer biomarkers discovery.

ESI-MS (/MS): Electrospray ionization MS (ESI-MS) and often the tandem mass MS (ESI-MS/MS) are largely implemented in proteomic platforms for protein identification and quantitation from complex samples, including target protein characterization and biomarkers discovery. More often the ESI-MS/MS is used online with a nano-LC system where the sensitivity and the capacity of this soft ionization and identification technique are fully explored for proteomic applications. This hyphenation generates more information in a given time and it is also more suitable for relative quantification due to the ionization suppression issues linked to the complexity of biospecimens when analyzed with ESI-MS/MS or MALDI-MS.

On the other hand, the quantitative proteomics based on LCMS/MS approaches has led to major development in the discovery of novel cancer biomarkers and potential therapeutic targets during the last decade. Indeed, LC-MS/MS is easily combined with quantitative techniques such as isotope-coded affinity tags (ICAT), isobaric tags for relative and absolute quantification (iTRAQ), or Stable Isotope Labeling By Amino Acids in Cell Culture (SILAC) [88-92]. Once introduced to the mass spectrometer, the mass shift due to labeling is easily detectable from the paired labeled versus native peptides or proteins and the quantification is achieved typically by calculating ratios between those paired species at MS or MS/MS levels. Therefore, proteins and peptides including putative biomarkers can be identified and quantified within

\begin{tabular}{|c|c|c|}
\hline Type of Cancer & Biospecimen & References \\
\hline Prostate & Urine & {$[152]$} \\
& Serum & {$[153]$} \\
\hline \multirow{2}{*}{ Breast } & Serum & {$[153-158]$} \\
& Nipple aspirate & {$[159]$} \\
& cerebrospinal fluid & {$[160]$} \\
\hline Colorectal & Urine & {$[161,162]$} \\
\hline Oral & Saliva & {$[163]$} \\
\hline Gastric & Plasma & {$[164,165]$} \\
\hline Ovarian & Serum & {$[166]$} \\
\hline Uterus & Serum & {$[26,34,35,48,157,167-169]$} \\
\hline Bladder & Serum & {$[153]$} \\
\hline Thyroid & Serum & {$[37,38]$} \\
\hline Brain tumor & Serum & {$[38]$} \\
\hline
\end{tabular}

Table 1: Examples of studies using MALDI-MS and human biospecimens for protein/peptide biomarker discovery in cancer.

\begin{tabular}{|c|c|c|}
\hline Type of Cancer & Biospecimen & References \\
\hline Prostate & Serum & {$[170-172]$} \\
\hline \multirow{3}{*}{ Breast } & Saliva & {$[173]$} \\
& Serum & {$[81,174-180]$} \\
Plasma & {$[181]$} \\
\hline Colorectal & Nipple aspirate/ Ductal lavage & {$[182-192]$} \\
\hline Gastric & Serum & {$[83,193,194]$} \\
\hline & Serum & {$[166,195]$} \\
\hline Ovarian & Urine & {$[196]$} \\
& Serum & {$[20,197-202]$} \\
\hline Cervical & Plasma & {$[203,204]$} \\
\hline Bladder & Plasma & {$[205]$} \\
\hline Renal & Urine & {$[206]$} \\
\hline Melanoma & Urine & {$[207]$} \\
\hline $2:$ Serum & {$[181]$} \\
\hline
\end{tabular}

Table 2: Examples of studies using SELDI-MS and human biospecimens for protein/peptide biomarker discovery in cancer. 
the same experiment. This is particularly important for the analysis of low-molecular-weight fraction of the proteome (small polypeptides), where the standard biochemical assays such as Enzyme-Linked Immunosorbent Assay (ELISA) and enzymatic tests are less efficient.

For example, ICAT-based quantitative proteomics has been used to identify potential biomarkers of pancreatic cancer [93], ovarian cancer [94], and breast cancer [95] or in human myeloid leukemia (HL-60) cells [96]. The iTRAQ-based approach have been also widely employed in cancer research, including head-and-neck squamous cell carcinoma [97], cancer angiogenesis [98], metastasis [99], epithelial mesenchymal transition [100], cancer therapy resistance [101], and cancer secretome [102]. SILAC-based approach was used in comprehensive proteomics analysis of MLL [103], or to identify metastasis-associated proteins to understand cancer progression and predict prognosis, such as in patients with HCC, mammary, and melanoma cancers [104-106]. Comprehensive quantification of human tumors was also made possible by spiking the human samples with a mixture of SILAC labeled cancer cell lines [107]. This approach is promising for the discovery of reliable cancer biomarkers by using the appropriate labeled cell lines.

As an alternative to isotope labeling, label-free quantification provides simple, low-cost and technically less stringent measurements of cancerous proteomes [108]. The straightforward method is a relative quantification based on peptides/ proteins identified from spectra (spectral counting) with the assumption that precursor-ion intensities correlate with peptide abundance [109]. Samples from patients and controls for examples are analyzed separately, but using the same data acquisition protocol. Label-free quantification approach usually needs more biological samples and experimental replicates than labeling approaches aside with run-to-run high reproducibility. This approach has been used in a number of oncoproteomic analyses [110]. Appropriate bioinformatics tools for spectra alignment and peptide quantification is warranted for more confidence and future success of label-free quantitative analysis [111].

Although the fact that LC-MS/MS is mostly used in the 'bottomup' approach, some exciting applications based on the 'top-down' approach were recently developed using these platforms which may give new opportunities for cancer proteomic applications (for example see, $[112,113])$.

\section{Perspectives for Cancer Proteomics}

Despite the tremendous progress in the MS technologies as well as in the development standardized experimental protocols for enrichment, separation, identification and quantification of proteins, proteomics research is still limited by both technologies and bioinformatics tools currently available for analyzing proteins. Indeed, the complex nature of the human proteome, the huge dynamic range of protein concentration and the plethora of protein isoforms in specimens added to the heterogeneity in diseases are major hurdle to overcome in proteomics [114]. On the other hand, most of initial proteomic studies were designed on a 'snapshot' basis, where only a single time point from a given human sample was investigated without taking into account significant processes taking place over time. Therefore, recent studies started to look at serial-time points to get access to the temporal and special dynamics of proteins, in particular for screening and early detection of cancer and have shown promising results (see for example $[34,35])$. Furthermore, neither the so-called data-based strategy nor the hypothesis-based strategy were able to deliver the expected outcomes from proteomic studies and the combination of both of them will definitely help in deciphering more secrets of disease-linked proteome and accelerating the path from the bench-side to the bedside [115].

Taken together with the new metamorphosis happening in the proteomic field by including collaborative and inter-disciplinary efforts, some promising perspectives are foreseen for the near future. These include; retuning some previous approaches, developing new ones and combining proteomics with other 'omics' approaches around more targeted biological questions and strategies. In an attempt to evaluate the most common MS-based proteomic platforms, we summarized in table 3, the effectiveness and usefulness of these platforms for biomarker discovery and/or clinical diagnosis in the field of cancer.

\section{Targeted MS-based proteomics}

During the last decade, intensive work was carried out and aiming a general profiling of various accessible biofluids in the quest of new cancer biomarkers. Nevertheless, this strategy has shown its limitations due to the complexity of those biospecimens with high dynamic range and in which the most potential biomarkers leaked from tumors are available in many orders of magnitude less than the common proteins in those samples. Therefore, a more targeted or directed strategy became mandatory to give onco-proteomic studies a new breath with promising future.

Targeting diseased tissues and proximal fluids for biomarkers discovery: It is obvious that in tumor tissues and their proximal fluids (cerebrospinal fluid, tumor interstitial fluid, nipple aspirate, etc.), tumor-derived proteins are present at higher concentration than in the bloodstream to which protein biomarkers may be secrete or leaked. Therefore, targeting those local sites will dramatically increase the possibility of isolating and identifying cancer-specific markers [116,117]. According to this approach, potential biomarkers will be first discovered in the tumors or their proximal fluids and then measured out in the plasma using highly sensitive, targeted assay technologies. This subsequent step is critical to check if biomarker candidates are available in detectable amounts in blood, either by MS or other independent assays, and thus the possibility of developing non-invasive blood-based tests for cancer diagnosis or screening. This approach was recently used with success for prioritizing candidate markers linked to breast cancer [118] and cardiac injury [119] by combining the biomarker candidate identification from tissue and then peripheral blood with targeted MS (accurate inclusion mass screening and SRM) to detect only the preselected peptides.

As gene expression profiling studies are carried out using tissues and cells, this proteomic targeted strategy has also the advantage of using the same tumor tissue for the validation of candidate biomarkers by combining genomic and proteomic data [18]

Another approach to target biomarkers is to work directly on the subcellular organelles (membranes, nucleus, mitochondria, endoplasmic reticulum, etc) rather than working on the whole cell extracts. For instance, this will help in obtaining clear idea about spatial distribution of proteins and their translocation between cell compartments as well as linking proteins to their function in a specific organelle (for example, drug receptors at cell surface, transport mechanisms by vesicles or cell fate decisions at mitochondria) [25]

Targeting post-translation modifications: Post-Translation Modifications (PTMs) such as glycosylation, phosphorylation, acetylation, methylation, and ubiquitination induce structural and functional changes in most of proteins and play key role in the genesis and progress of cancer. At least one-third of intracellular protein 
Citation: Khadir A, Tiss A (2013) Proteomics Approaches towards Early Detection and Diagnosis of Cancer. J Carcinogene Mutagene S14: 002. doi:10.4172/2157-2518.S14-002

Page 8 of 16

\begin{tabular}{|c|c|c|c|c|c|c|c|c|c|}
\hline \multirow[b]{2}{*}{ Technique } & \multirow[b]{2}{*}{ Application } & \multirow{2}{*}{$\begin{array}{l}\text { Protein } \\
\text { Pattern }\end{array}$} & \multirow{2}{*}{$\begin{array}{c}\text { Identification } \\
\text { (protein/sample) }\end{array}$} & \multirow{2}{*}{$\begin{array}{c}\text { Quantification } \\
\text { (protein/sample) }\end{array}$} & \multirow{2}{*}{$\begin{array}{c}\text { throughput } \\
\text { (sample / day) }\end{array}$} & \multirow[b]{2}{*}{ Information } & \multirow{2}{*}{$\begin{array}{c}\text { Ease of } \\
\text { use }\end{array}$} & \multicolumn{2}{|c|}{ Cost effectiveness } \\
\hline & & & & & & & & $\begin{array}{c}\text { Biomarker } \\
\text { discovery }\end{array}$ & $\begin{array}{c}\text { Clinical } \\
\text { Diagnosis }\end{array}$ \\
\hline SELDI-MS & Proteins, peptides & +++ & - & - & $>1000$ & + & +++ & ++ & +++ \\
\hline MALDI-MS & Proteins, peptides & +++ & - & - & $>1000$ & ++ & +++ & ++ & +++ \\
\hline LC-MS & Proteins, peptides & ++ & - & - & $>20$ & +++ & ++ & + & ++ \\
\hline MALDI-MS/MS & Proteins, peptides & - & $>10$ & - & $>100$ & ++ & ++ & ++ & ++ \\
\hline LC-MS/MS & $\begin{array}{l}\text { Proteins, peptides, } \\
\text { metabolites }\end{array}$ & - & $>100$ & $>100$ & $>10$ & +++ & ++ & +++ & + \\
\hline 2D-LC-MS/MS (MudPIT) & $\begin{array}{l}\text { Proteins, peptides, } \\
\text { metabolites }\end{array}$ & - & $>1000$ & $>500$ & $<1$ & +++ & + & +++ & + \\
\hline 1D-GE - MALDI-MS(/MS) & Proteins, peptides & - & $<100$ & $<100$ & $<1$ & +++ & ++ & +++ & + \\
\hline 1D-GE - LC-MS/MS & Proteins, peptides & - & $>100$ & $>100$ & $<1$ & +++ & ++ & +++ & + \\
\hline 2D-GE - MALDI-MS(/MS) & Proteins, peptides & - & $>200$ & $>200$ & $<1$ & +++ & + & +++ & + \\
\hline LC-MS/MS (MRM) & Proteins, peptides & - & - & $>100$ & $>20$ & + & + & + & + \\
\hline MALDI-MSI & $\begin{array}{l}\text { Proteins, peptides, } \\
\text { metabolites }\end{array}$ & ++ & - & - & $<10$ & + & + & ++ & +++ \\
\hline SPR(-MS) & $\begin{array}{l}\text { DNA, RNA, proteins, } \\
\text { metabolites }\end{array}$ & - & + & ++ & $>10$ & +++ & ++ & ++ & + \\
\hline
\end{tabular}

Table 3: Throughput, usefulness and cost effectiveness of various MS-based proteomic platforms for biomarker discovery and clinical diagnosis of cancer.

might be phosphorylated [120] and more than 50\% of mammalian proteins are glycosylated [8]. PTMs in proteins, however, make almost impossible to identify and quantify all isoforms of the same protein in a single experiment. Indeed, these modifications are characterized both by their very dynamic nature and low stoichiometry [19]. Thus, enrichment of specific and homogenous sub-proteome is becoming a routine procedure to increase the potential of discovered biomarkers. Many cancer proteomics studies have already focused on proteins with specific PTMs and resulted in promising results linked to the involvement of new pathways and enzymes in this disease (for example; [8,38,121-124]). These kind of selective studies were even more facilitated recently with the development of ionization techniques such as Electron Transfer Dissociation (ETD) leaving labile PTMs intact on the peptide backbone. Furthermore, the study of the human kinome (the complement set of protein kinases responsible for protein phosphorylation) associated with clinical outcomes would clarify disease mechanisms, identify therapy targets, and develop predictive applications [125]. The glycoproteome is also of particular interest because most traditional cancer biomarkers are glycoproteins and changes in patterns of glycosylation have been reported in cancer cells and it is thought to continue to be main source of biomarkers $[121,126]$. Despite all progress achieved in MS technology and sample preparation and PTMs enrichment, there still an effort to be done regarding the data analysis as most of the current available software can't cope with multiple PTMs on a single protein [19].

Targeting interactome: Protein interactions play a critical role in regulating of biological functions both at cellular and organism levels as most proteins exert their function as part of multiprotein complexes. Unraveling the interactome in space and time promise to be a key step towards understanding and modeling the complex cellular functions and behavior in cancer onset and progress. This systemslevel understanding will shed light on the behavior of both proteins and genes in their networks and may represent functional molecular groups that play important roles in the disease process as descent biomarkers to be targeted [18]. This may hold considerable promise in improving drug efficacy as tumor cells may escape the treatment through alternative pathways or secondary interactions. For instance, the cellular pathways are highly dynamic and interconnected, probably to generate functional redundancy and compensating mechanisms should parts of a pathway become unavailable [25].
Protein-protein interaction is now studied by combining affinity purification, under near physiological conditions, with MS to identify protein interaction partners [19]. As example, expression profiles and protein interaction information were integrated and protein interaction networks with expression patters were identified [127-129] and were then shown to be predictive of breast cancer prognosis.

One, however, needs to bear in mind when studying interactome that many biologically relevant protein interactions will likely not survive the sample preparation steps and may only be measured with in vivo methods. Furthermore, some interactions that lack biological significance may be also introduced during sample processing and cell lysis. Therefore, the right biological and experimental controls should be included to ensure meaningful results.

\section{Selected reaction monitoring quantitation}

Although large numbers of putative cancer biomarkers were identified through various studies and approaches, the appropriate validation with reasonable throughput and cost is still representing a bottleneck for the biomarker development pipelines [130].

Selected Reaction Monitoring (SRM), also called Multiple Reaction Monitoring (MRM) is an emerging quantification strategy [131]. In this targeted approach, a protein of interest is selected for quantification based on its unique precursor peptides and their consecutive fragments (called transition) and analyzed using a of triple quadrupole- or linear ion trap mass spectrometers. To ensure good quantification, at least two peptides per protein and two fragment ions are monitored (minimum of four transitions per protein) during the SRM. Due to its sensitivity and specificity, SRM approach can even be used from unfractionated samples but it requires that several peptides from the targeted protein and their fragments should be known in advance through initial LC-MS runs $[132,133]$. This makes SRM-type quantification more elaborated than conventional label-free quantification.

Due to its multiplexibility, specificity, and sensitivity, SRM can be used for validation of a single protein of interest but also for large-scale proteome validation [134]. Furthermore, SRM-based quantitation ensures good reproducibility across multiple laboratories [132] and can cover a high dynamic range and for a reasonable number of samples.

For more rapid and cost-effective absolute quantitation and validation of biomarkers of interest, an optimized strategy called 
'Monitoring initiated detection and sequencing-multiple reaction monitoring (MIDAS-MRM)' was recently developed to avoid the requirement of immunoassay-based validation techniques which require a costly and time-consuming development of specific antibodies for the targeted biomarkers [135]. Whiteaker et al. [118] have also, for example, developed a targeted proteomics-based pipeline for verification of biomarkers in plasma based first on triage of the most promising biomarkers to be then verified with SRM. Therefore, SRM might be used as standalone quantitation method in clinical environment with a particular advantage of being specific and reasonably cost-effective as many triple quadripole MS machines are already established in clinical labs.

\section{MALDI-Imaging}

Direct tissue analysis by MALDI MS imaging (MALDI-MSI) is a fast and multiplexed approach that opens the door to new perspectives in clinical proteomics and it may become a valuable alternative to immunohistochemistery [68,136-139].

MALDI-MSI has the unique feature to give access to the anatomical dimension or space distribution of markers in the tissue, an information usually lost in liquid or tissue-extracted samples [140]. Moreover, starting the biomarker mining at the disease-source tissue using MALDI-MSI will shorten the path to fish new disease-specific proteins. Accessible body fluids such as blood, urine or saliva can be then used for verification of the presence of these specific markers in the aim of developing non-invasive tests for cancer diagnosis or screening. Another advantage of MALDI-MSI is the possibility to analyze the tissue biopsies both using top-down and bottom-up approaches as many protocols were already tuned for this purpose and allowing direct identification and quantitation of proteins and peptides on tissues [141-143]. Tissue profiling from large set of biopsy samples is now possible due to the availability of appropriate algorithms for pattern comparison allowing molecular tissue classification.

The development of $3 \mathrm{D}$ reconstruction of the tissue composition through the imaging of many successive tissue sections started to give the opportunity to reconstruct the complete tumor maps linked to specific marker distribution [144]. This will help to make the right medical decision, in particular if MALDI-MSI is combined with other known histological and pathophysiological data of the same tissue obtained for example from PET, CTscan or MRI. Other directions to integrate MALDI-MSI into clinical settings include for example; development of profile signature diagnosis for early detection of disease and to complement histopathology, assessment of therapeutic efficacy and toxicity or drug resistance which may help in tailoring personal an efficient treatment [140]. All these developments and unique advantages are sought to make soon from MALDI-MSI a key platform in clinical histopathology and may provide a new descent tool for multiplexed cancer diagnosis [140,145].

Nevertheless, some extra efforts are pre-requisite to see the MALDI-MSI well established on the bedside, these include more standardization in sample preparation as well as in data acquisition and analysis protocols aside with improvement in resolution which didn't yet reach the subcellular levels.

\section{Surface Plasmon resonance-MS}

Recent developments have led to a closer integration of key technologies, providing a combined approach to enable full characterization (identification, quantitation, interaction, and function) of proteins from complex biospecimens. Chip-based Surface
Plasmon Resonance (SPR) is an analytical, label-free, real time-reading biosensor that utilizes interaction of light photons with free electrons (surface plasmons) on a gold surface to quantify the changes in binding amount of biomaterial on the surface $[146,147]$. SPR biosensors are often referred as mass detectors because the mass of the molecules directly influences the signal reading. SPR, in particular BiAcore, biosensors gained enormous popularity in biomedical research and pharmaceutical industry due to their sensitivity, robustness, flexibility and their amenability to automation and throughput. One of the features of the technique is the possibility to obtain real-time data on the interaction of a ligand and its receptor allowing kinetic data to be determined aside with an accurate determination of the amount of ligand [148]. Moreover, compared to other technologies the amount of material necessary to perform the experiments is less, labeling is not required and variation in surface chemistries is possible, allowing various immobilization strategies and interaction experiments.

Several studies used SPR to detect cancer biomarkers at clinically relevant concentrations highlighting the feasibility of using SPR in a clinical setting and analyzing various specimens such as plasma, serum, saliva and tissues (for review see [149]). However, obtaining high sensitivity in complex biological samples under real physiological conditions remains one of the major challenges for bioanalytical applications with SPR biosensors. The combination of SPR with MS made a powerful platform for pairing the unique advantage of interaction affinity analysis by SPR with ligand identification by MS to further apprehend functional proteomics investigations. Here, proteins are affinity-purified, quantified and characterized in terms of their interactions, while the mass spectrometer identifies and structurally characterizes the biomolecules. Nevertheless, there are still some bottlenecks facing this technology coupling, including binding capacity and specificity of SRP sensor surface when using complex samples and the low throughput added to the relatively high cost of these systems.

SPR-MS hyphenation started recently to be used for cancer studies. For example, the use of SPR-MS enabled multiplexed- biding quantitation and the characterization of potential breast cancer marker (LAG3 protein) from plasma [150,151]. Table 4 is summarizing a selected list of studies published using SPR platforms for cancer biomarkers discovery.

\section{Omics integration}

Protein biomarkers are expected to provide more direct answers to biological and clinical questions than genomic or transcriptomic data, as the majority of known molecular markers and pharmaceutical targets are indeed proteins. Nevertheless, and despite rapid advances in the past decade, protein identification and quantification technologies still lag behind those used in DNA sequencing and mRNA expression profiling on a genome-wide scale. This is mainly due to the fact that proteins are extremely complex and dynamic, their changes are more difficult to monitor compared to genomic profiling [5]. Therefore, the integration of the data generated from various omics approaches such as genomics, transcriptomics, proteomics and metabolomics, in a system biology approach, will help in making meaningful hypotheses and foster the discovery of real biomarkers by reducing the false positive rates at the discovery and validation stages (Figure 3 for a summary of the combined approaches). Obviously, this needs to put scientists, clinicians, bioinformaticians and technologists all together for coordinated collaboration and will dramatically reduce the research costs and may shorten the way to win the battle against cancer. For example, Kulasingam et al. [12] have combined multiple data sets of 
Citation: Khadir A, Tiss A (2013) Proteomics Approaches towards Early Detection and Diagnosis of Cancer. J Carcinogene Mutagene S14: 002. doi:10.4172/2157-2518.S14-002

Page 10 of 16

\begin{tabular}{|c|c|c|c|}
\hline Type of Cancer & Biomarkers & Approach and Limit of Detection & References \\
\hline Prostate & PSA & Immunosensor, imaging and localized SPR approaches, limit of detection ranges from $0.3 \mathrm{fM}$ to $10 \mathrm{nM}$. & [209-214] \\
\hline Breast & $\begin{array}{l}\text { BRCA1 } \\
\text { CA-15.3 } \\
\text { LOX-12 } \\
\text { CD24 }\end{array}$ & $\begin{array}{l}\text { DNA functionalized SPR sensor surface using vertical and lateral spacers, detection limit below } 50 \mathrm{nM} \text {. } \\
\text { Au/ZnO activated films used for SPR sensor surface, detection limit of } 0.025 \mathrm{U} / \mathrm{ml} \text {. } \\
\text { Antibody functionalized SPR sensor surface, detection limit is } 9 \times 10^{-2} \mathrm{ng} / \mathrm{ml} \text {. } \\
\text { E-Selectin functionalized SPR sensor surface. }\end{array}$ & $\begin{array}{l}{[215]} \\
{[216]} \\
{[217]} \\
{[218]}\end{array}$ \\
\hline Colorectal & $\begin{array}{c}\text { CEA } \\
\text { VEGF } \\
\text { Transgelin-2 \& ALCAM/CD }\end{array}$ & $\begin{array}{l}\text { Immunosensor SPR using protein A or G or HRP conjugated antibody for signal enhancement, range of } \\
\text { detection } 25 \mathrm{ng} / \mathrm{ml} \text { to } 125 \mathrm{ng} / \mathrm{ml} \\
\text { RNA aptamer funtionalized SPR sensor surface, limit of detection at pM } \\
\text { Polarized SPR imaging for signal sensitivity, detection limit } 3-6 \mathrm{ng} / \mathrm{ml}\end{array}$ & $\begin{array}{l}{[219,220]} \\
{[221]} \\
{[222]}\end{array}$ \\
\hline Oral & COX2 \& IL-8 & Immunosensor and microfluidic channel SPR, limit of detection 250 pM & {$[223,224]$} \\
\hline Pancreatic & AICAM \& hCG & $\begin{array}{l}\text { Immunosensor SPR or SPR imaging using antibody chip using an oligonucleotide linker, limits of } \\
\text { detection are } 0.5-1 \mathrm{ng} / \mathrm{ml} \text { or } 50 \mathrm{ng} \text {. }\end{array}$ & {$[225,226]$} \\
\hline Gastric & MG-7 & SPR biosensor & [227] \\
\hline Hepatic & AFP & ELISA type on SPR sensor, limit of detection $700 \mathrm{ng} / \mathrm{ml}$ & [228] \\
\hline Lung & proGRP & aptamer funtionalized SPR sensor surface & [229] \\
\hline Ovarian & HE4 & Localized SPR immunobiosensor for detecting HE4 in blood samples, limit of detection 4 pM. & [230] \\
\hline
\end{tabular}

Table 4: Examples of studies using SPR platforms for cancer biomarkers discovery.
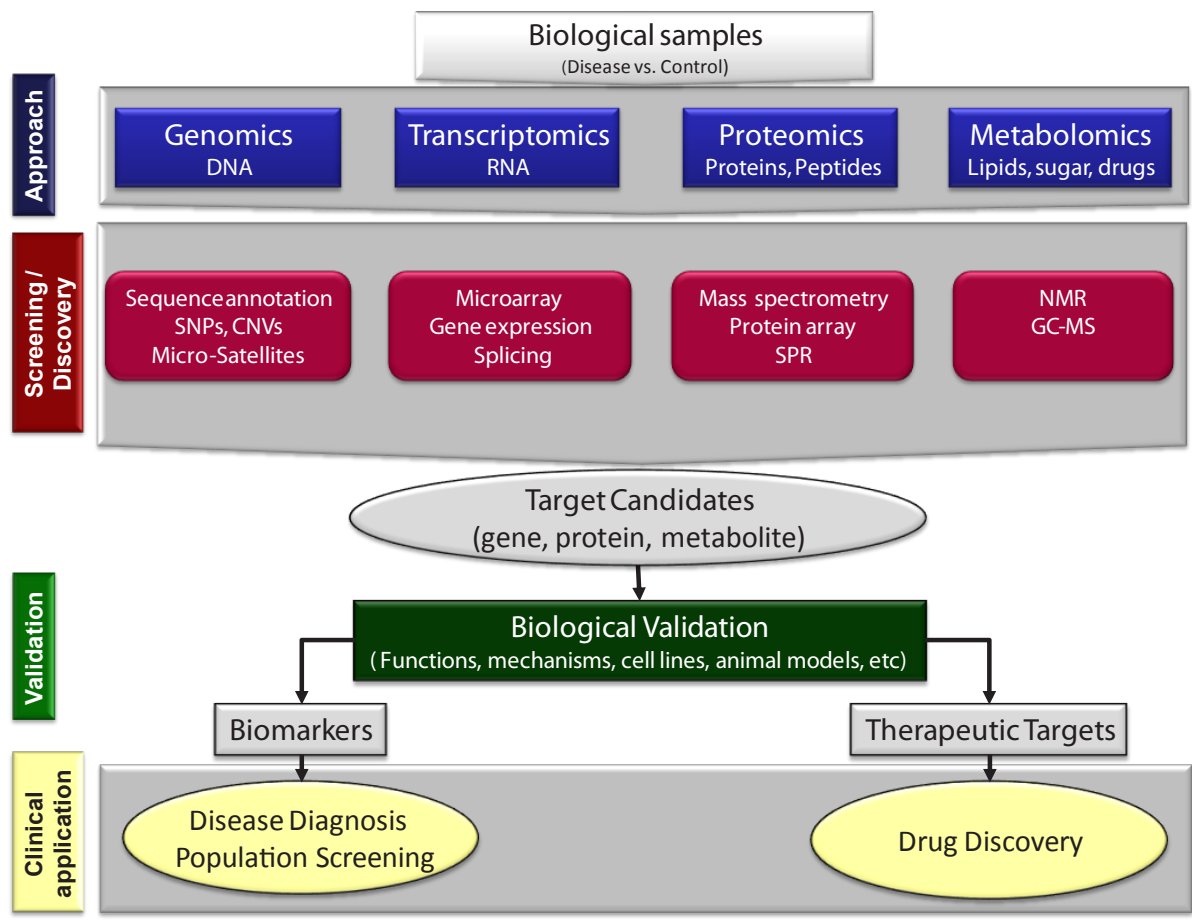

Figure 3: Integration of 'Omics' for the biomarker discovery, validation and clinical applications.

biomarker candidates, including clinical ascites fluid and various cell lines, linked to ovarian cancer and have applied numerous filters, they selected for further validation only 2 promising biomarkers out of many hundreds initially identified.

Moreover, to date there have been more genomics experiments and genome coverage achieved by gene profiling, carried out in large scale clinical studies, than proteomics experiments. Thus, including these genomics data sets in the candidates database helps to better incorporate clinical information (e.g., disease outcomes) in the discovery stage [18].

Briefly, there is a clear need to make use of every piece of information available on cancer biology and pathophysiology, by implementing an integrative approach using multiple "omics" data sets to improve biomarker identification and validation with the perspective to develop specific and sensitive clinical caner markers or drug targets.

\section{Conclusions}

The development of MS technologies and proteomic field has enabled generating huge amount of data characterizing the proteome of complex biological samples as well understanding further cancer biology. Comparative analyses of samples from healthy and diseased persons became possible for the identification of thousands of potentially specific biomarkers. In addition, the development of validation platforms such as SRM and microarrays that offer the potential for highly multiplexed and sensitive analysis of the proteome is an advantage towards the development of new protein biomarkers. 
Citation: Khadir A, Tiss A (2013) Proteomics Approaches towards Early Detection and Diagnosis of Cancer. J Carcinogene Mutagene S14: 002. doi:10.4172/2157-2518.S14-002

The transfer of biomarkers from the discovery field to clinical use is still, however, on a road coated with some technical and physiologylinked pitfalls.

On the other hand, and although the MS-based proteomics approaches did not yet deliver the promised descent cancer biomarkers to the clinics, it did increase dramatically our knowledge about cancer biology and helped in involving large scientific and industrial communities in the development of highly sensitive and accurate tools and strategies. Fortunately, and to meet proteomics potential for finding biomarkers, clinicians, statisticians, epidemiologists and chemists started to work together in an interdisciplinary approach to answer to a same question from different fields of expertise. Finally, the most recent developments in MS technologies and targeted proteomicbased approaches have given a great but reasonable hope, and note hype, to the field of cancer biomarker discovery.

\section{References}

1. Banks RE, Dunn MJ, Hochstrasser DF, Sanchez JC, Blackstock W, et al. (2000) Proteomics: new perspectives, new biomedical opportunities. Lancet 356: 1749-1756.

2. Ewing B, Green $P$ (2000) Analysis of expressed sequence tags indicates 35,000 human genes. Nat Genet 25: 232-234.

3. Pertea M, Salzberg SL (2010) Between a chicken and a grape: estimating the number of human genes. Genome Biol 11: 206.

4. Anderson NL, Anderson NG (2002) The human plasma proteome: history, character, and diagnostic prospects. Mol Cell Proteomics 1: 845-867.

5. Greenbaum D, Colangelo C, Williams K, Gerstein M (2003) Comparing protein abundance and mRNA expression levels on a genomic scale. Genome Biol 4: 117.

6. Vogel C, Abreu Rde S, Ko D, Le SY, Shapiro BA, et al. (2010) Sequence signatures and mRNA concentration can explain two-thirds of protein abundance variation in a human cell line. Mol Syst Biol 6: 400.

7. Li G, Xiao Z, Liu J, Li C, Li F, et al. (2011) Cancer: a proteomic disease. Sci China Life Sci 54: 403-408.

8. Tan HT, Lee YH, Chung MC (2012) Cancer proteomics. Mass Spectrom Rev 31: 583-605.

9. Hanash SM, Baik CS, Kallioniemi O (2011) Emerging molecular biomarkers-blood-based strategies to detect and monitor cancer. Nat Rev Clin Oncol 8 . $142-150$.

10. Parekh DJ, Ankerst DP, Troyer D, Srivastava S, Thompson IM (2007) Biomarkers for prostate cancer detection. J Urol 178: 2252-2259.

11. Nossov V, Amneus M, Su F, Lang J, Janco JM, et al. (2008) The early detection of ovarian cancer: from traditional methods to proteomics. Can we really do better than serum CA-125? Am J Obstet Gynecol 199: 215-223.

12. Kulasingam V, Pavlou MP, Diamandis EP (2010) Integrating high-throughput technologies in the quest for effective biomarkers for ovarian cancer. Nat Rev Cancer 10: 371-378.

13. Sarandakou A, Protonotariou E, Rizos D (2007) Tumor markers in biological fluids associated with pregnancy. Crit Rev Clin Lab Sci 44: 151-178.

14. Bagan P, Berna P, Assouad J, Hupertan V, Le Pimpec Barthes F, et al. (2008) Value of cancer antigen 125 for diagnosis of pleural endometriosis in females with recurrent pneumothorax. Eur Respir J 31: 140-142.

15. Sun Y, Mi W, Cai J, Ying W, Liu F, et al. (2008) Quantitative proteomic signature of liver cancer cells: tissue transglutaminase 2 could be a novel protein candidate of human hepatocellular carcinoma. J Proteome Res 7: 3847-3859.

16. Carr SA, Anderson L (2008) Protein quantitation through targeted mass spectrometry: the way out of biomarker purgatory? Clin Chem 54: 1749-1752.

17. Ludwig JA, Weinstein JN (2005) Biomarkers in cancer staging, prognosis and treatment selection. Nat Rev Cancer 5: 845-856.

18. Wang P, Whiteaker JR, Paulovich AG (2009) The evolving role of mass spectrometry in cancer biomarker discovery. Cancer Biol Ther 8: 1083-1094.
19. Altelaar AF, Munoz J, Heck AJ (2013) Next-generation proteomics: towards an integrative view of proteome dynamics. Nat Rev Genet 14: 35-48.

20. Petricoin EF, Ardekani AM, Hitt BA, Levine PJ, Fusaro VA, et al. (2002) Use of proteomic patterns in serum to identify ovarian cancer. Lancet 359: 572-577.

21. Palmblad M, Tiss A, Cramer R (2009) Mass spectrometry in clinical proteomics - from the present to the future. Proteomics Clin Appl 3: 6-17.

22. Luna Coronell JA, Syed P, Sergelen K, Gyurján I, Weinhäusel A (2012) The current status of cancer biomarker research using tumour-associated antigens for minimal invasive and early cancer diagnostics. J Proteomics 76 Spec No.

23. Baak JP, Janssen EA, Soreide K, Heikkilae R (2005) Genomics and proteomics-the way forward. Ann Oncol 16 Suppl 2: ii30-44.

24. Gast MC, Schellens JH, Beijnen JH (2009) Clinical proteomics in breast cancer a review. Breast Cancer Res Treat 116: 17-29.

25. Mallick P, Kuster B (2010) Proteomics: a pragmatic perspective. Nat Biotechno 28: 695-709.

26. Tiss A, Smith C, Menon U, Jacobs I, Timms JF, et al. (2010) A well-characterised peak identification list of MALDI MS profile peaks for human blood serum. Proteomics 10: 3388-3392.

27. Normanno N, Campiglio M, De LA, Somenzi G, Maiello M, et al. (2002) Cooperative inhibitory effect of ZD1839 (Iressa) in combination with trastuzumab (Herceptin) on human breast cancer cell growth. Ann Oncol 13: 65-72.

28. Zwick E, Bange J, Ullrich A (2002) Receptor tyrosine kinases as targets for anticancer drugs. Trends Mol Med 8: 17-23.

29. Kulasingam V, Diamandis EP (2008) Strategies for discovering novel cance biomarkers through utilization of emerging technologies. Nat Clin Pract Onco 5: 588-599.

30. Wulfkuhle J, Espina V, Liotta L, Petricoin E (2004) Genomic and proteomic technologies for individualisation and improvement of cancer treatment. Eur $\mathrm{J}$ Cancer 40: 2623-2632.

31. Latterich M, Abramovitz M, Leyland-Jones B (2008) Proteomics: new technologies and clinical applications. Eur J Cancer 44: 2737-2741.

32. Jurisicova A, Jurisica I, Kislinger T (2008) Advances in ovarian cancer proteomics: the quest for biomarkers and improved therapeutic interventions. Expert Rev Proteomics 5: 551-560.

33. Paulovich AG, Whiteaker JR, Hoofnagle AN, Wang P (2008) The interface between biomarker discovery and clinical validation: The tar pit of the protein biomarker pipeline. Proteomics Clin Appl 2: 1386-1402.

34. Tiss, A, Timms JF, Smith C, Devetyarov D, Gentry-Maharaj A, et al. (2011) Highly accurate detection of ovarian cancer using CA125 but limited improvement with serum matrix-assisted laser desorption/ionization time-offlight mass spectrometry profiling. Int J Gynecol Cancer 20: 1518-1524.

35. Timms JF, Menon U, Devetyarov D, Tiss A, Camuzeaux S, et al. (2011) Early detection of ovarian cancer in samples pre-diagnosis using CA125 and MALDIMS peaks. Cancer Genomics Proteomics 8: 289-305.

36. Timms JF, Menon U, Devetyarov D, Tiss A, Camuzeaux S, et al. (2011) Early detection of ovarian cancer in samples pre-diagnosis using CA125 and MALDIMS peaks. Cancer Genomics Proteomics 8: 289-305.

37. Villanueva J, Martorella AJ, Lawlor K, Philip J, Fleisher M, et al. (2006) Serum peptidome patterns that distinguish metastatic thyroid carcinoma from cancerfree controls are unbiased by gender and age. Mol Cell Proteomics 5: 18401852.

38. Villanueva J, Nazarian A, Lawlor K, Yi SS, Robbins RJ, et al. (2008) A sequence-specific exopeptidase activity test (SSEAT) for "functional" biomarker discovery. Mol Cell Proteomics 7: 509-518.

39. Villanueva J, Philip J, Entenberg D, Chaparro CA, Tanwar MK, et al. (2004) Serum peptide profiling by magnetic particle-assisted, automated sample processing and MALDI-TOF mass spectrometry. Analytical Chemistry 76 1560-1570.

40. Zhang Z, Chan DW (2010) The road from discovery to clinical diagnostics: lessons learned from the first FDA-cleared in vitro diagnostic multivariate index assay of proteomic biomarkers. Cancer Epidemiol Biomarkers Prev 19: 2995 2999.

41. Downing M, Pollitt R (2008) Newborn bloodspot screening in the UK--past present and future. Ann Clin Biochem 45: 11-17. 
Citation: Khadir A, Tiss A (2013) Proteomics Approaches towards Early Detection and Diagnosis of Cancer. J Carcinogene Mutagene S14: 002. doi:10.4172/2157-2518.S14-002

Page 12 of 16

42. Frazier DM, Millington DS, McCandless SE, Koeberl DD, Weavil SD, et al. (2006) The tandem mass spectrometry newborn screening experience in North Carolina: 1997-2005. J Inherit Metab Dis 29: 76-85.

43. Wilcken B, Wiley V, Hammond J, Carpenter K (2003) Screening newborns for inborn errors of metabolism by tandem mass spectrometry. N Engl J Med 348 2304-2312.

44. Lacroix, P, Goedesky G (2011) Bruker's IVD MALDI Biotyper Now Available to Clinical Microbiology Sites in Canada for Proteomic Identification of Microorganisms.

45. Khot PD, Couturier MR, Wilson A, Croft A, Fisher MA (2012) Optimization of matrix-assisted laser desorption ionization-time of flight mass spectrometry analysis for bacterial identification. J Clin Microbiol 50: 3845-3852.

46. Whiteaker JR, Zhang H, Zhao L, Wang P, Kelly-Spratt KS, et al. (2007) Integrated pipeline for mass spectrometry-based discovery and confirmation of biomarkers demonstrated in a mouse model of breast cancer. J Proteome Res 6: 3962-3975.

47. Gramolini AO, Peterman SM, Kislinger T (2008) Mass spectrometry-based proteomics: a useful tool for biomarker discovery? Clin Pharmacol Ther 83: 758-760.

48. Tiss A, Smith C, Camuzeaux S, Kabir M, Gayther S, et al. (2007) Serum peptide profiling using MALDI mass spectrometry: avoiding the pitfalls of coated magnetic beads using well-established ZipTip technology. Proteomics 7 Suppl 1: 77-89

49. Villanueva J, Philip J, Chaparro CA, Li Y, Toledo-Crow R, et al. (2005) Correcting common errors in identifying cancer-specific serum peptide signatures. J Proteome Res 4: 1060-1072.

50. Diamandis EP (2004) OvaCheck: doubts voiced soon after publication. Nature 430: 611.

51. ISBER (2008) International Society for Biological and Environmental Repositories, ISBER: 2008 Best practices for repositories: collection, storage, retrieval and distribution of biological materials for research. Cell Preserv Technol 6: 5-58.

52. Leyland-Jones BR, Ambrosone CB, Bartlett J, Ellis MJ, Enos RA, et al. (2008) Recommendations for collection and handling of specimens from group breast cancer clinical trials. J Clin Oncol 26: 5638-5644.

53. Altman DG., McShane LM, Sauerbrei W, and Taube SE (2012) Reporting recommendations for tumor marker prognostic studies (REMARK): explanation and elaboration. BMC Med 10: 51.

54. Merril CR, Switzer RC, Van Keuren ML (1979) Trace polypeptides in cellular extracts and human body fluids detected by two-dimensional electrophoresis and a highly sensitive silver stain. Proc Natl Acad Sci U S A 76: 4335-4339.

55. Patton WF (2000) A thousand points of light: the application of fluorescence detection technologies to two-dimensional gel electrophoresis and proteomics. Electrophoresis 21: 1123-1144.

56. Lopez MF (1999) 2-D electrophoresis using carrier ampholytes in the first dimension (IEF). Methods Mol Biol 112: 111-127.

57. Unlü M, Morgan ME, Minden JS (1997) Difference gel electrophoresis: a single gel method for detecting changes in protein extracts. Electrophoresis 18: 2071 2077.

58. Koomen JM, Shih LN, Coombes KR, Li D, Xiao LC, et al. (2005) Plasma protein profiling for diagnosis of pancreatic cancer reveals the presence of host response proteins. Clin Cancer Res 11: 1110-1118.

59. Delahunty CM, Yates JR 3rd (2007) MudPIT: multidimensional protein identification technology. Biotechniques 43: 563, 565, 567 passim.

60. Liu H, Lin D, Yates JR 3rd (2002) Multidimensional separations for protein peptide analysis in the post-genomic era. Biotechniques 32: 898, 900, 902 passim.

61. Motoyama A, Venable JD, Ruse CI, Yates JR 3rd (2006) Automated ultra-highpressure multidimensional protein identification technology (UHP-MudPIT) for improved peptide identification of proteomic samples. Anal Chem 78: 51095118.

62. Cramer R (2009) MALDI MS. Methods Mol Biol 564: 85-103.

63. Veenstra TD, Prieto DA, Conrads TP (2004) Proteomic patterns for early cancer detection. Drug Discov Today 9: 889-897.
64. Qin XJ, Ling BX (2012) Proteomic studies in breast cancer (Review). Oncol Lett 3: 735-743.

65. Matharoo-Ball B, Ratcliffe L, Lancashire L, Ugurel S, Miles AK, et al. (2007) Diagnostic biomarkers differentiating metastatic melanoma patients from healthy controls identified by an integrated MALDI-TOF mass spectrometry/ bioinformatic approach. Proteomics Clin Appl 1:605-620.

66. Mian S, Ugurel S, Parkinson E, Schlenzka I, Dryden I, et al. (2005) Serum proteomic fingerprinting discriminates between clinical stages and predicts disease progression in melanoma patients. J Clin Oncol 23: 5088-5093.

67. Matharoo-Ball B, Miles AK, Creaser CS, Ball G, Rees R (2008) Serum biomarker profiling in cancer studies: a question of standardisation? Vet Comp Oncol 6: 224-247.

68. Bateson H, Saleem S, Loadman PM, Sutton CW (2011) Use of matrix-assisted laser desorption/ionisation mass spectrometry in cancer research. J Pharmacol Toxicol Methods 64: 197-206.

69. Callesen AK, Mogensen O, Jensen AK, Kruse TA, Martinussen T, et al. (2012) Reproducibility of mass spectrometry based protein profiles for diagnosis of ovarian cancer across clinical studies: A systematic review. J Proteomics 75: 2758-2772.

70. Galvão ER, Martins LM, Ibiapina JO, Andrade HM, Monte SJ (2011) Breast cancer proteomics: a review for clinicians. J Cancer Res Clin Oncol 137: 915925

71. Petricoin EF, Liotta LA (2004) SELDI-TOF-based serum proteomic pattern diagnostics for early detection of cancer. Curr Opin Biotechnol 15: 24-30.

72. Petricoin EF, Liotta LA (2004) Clinical proteomics: application at the bedside. Contrib Nephrol 141: 93-103.

73. Wiesner A (2004) Detection of tumor markers with ProteinChip technology Curr Pharm Biotechnol 5: 45-67.

74. Whelan LC, Power KA, McDowell DT, Kennedy J, Gallagher WM (2008) Applications of SELDI-MS technology in oncology. J Cell Mol Med 12: 15351547.

75. Diamandis EP (2004) Mass spectrometry as a diagnostic and a cancer biomarker discovery tool: opportunities and potential limitations. Mol Cell Proteomics 3: 367-378.

76. Kozak KR, Su F, Whitelegge JP, Faull K, Reddy S, et al. (2005) Characterization of serum biomarkers for detection of early stage ovarian cancer. Proteomics 5 4589-4596.

77. Malik G, Ward MD, Gupta SK, Trosset MW, Grizzle WE, et al. (2005) Serum levels of an isoform of apolipoprotein A-II as a potential marker for prostate cancer. Clin Cancer Res 11: 1073-1085.

78. Stattin P and Hakama M (2003) Serum protein fingerprinting coupled with a pattern-matching algorithm distinguishes prostate cancer from benign prostate hyperplasia and healthy men. Cancer Res., 62: 3609-3614, 2002. Cancer Res 63: 2701; author reply 2701-2702.

79. Petricoin EF, Ornstein DK, Liotta LA (2004) Clinical proteomics: Applications for prostate cancer biomarker discovery and detection. Urol Oncol 22: 322-328.

80. Lebrecht A, Boehm D, Schmidt M, Koelbl H, Grus FH (2009) Surface-enhanced Laser Desorption/lonisation Time-of-flight Mass Spectrometry to Detect Breast Cancer Markers in Tears and Serum. Cancer Genomics Proteomics 6: 75-83.

81. Becker S, Watson CP, Lynch H, Semmes OJ, et al. (2004) Surfaced-enhanced laser desorption/ionization time-of-flight (SELDI-TOF) differentiation of serum protein profiles of BRCA-1 and sporadic breast cancer. Ann Surg Oncol 11 907-914.

82. Ueda K, Fukase Y, Katagiri T, Ishikawa N, Irie S, et al. (2009) Targeted serum glycoproteomics for the discovery of lung cancer-associated glycosylation disorders using lectin-coupled ProteinChip arrays. Proteomics 9: 2182-2192.

83. Albrethsen J, Bøgebo R, Gammeltoft S, Olsen J, Winther B, et al. (2005) Upregulated expression of human neutrophil peptides 1, 2 and 3 (HNP 1-3) in colon cancer serum and tumours: a biomarker study. BMC Cancer 5: 8 .

84. Orvisky E, Drake SK, Martin BM, Abdel-Hamid M, Ressom HW, et al. (2006) Enrichment of low molecular weight fraction of serum for MS analysis of peptides associated with hepatocellular carcinoma. Proteomics 6: 2895-2902.

85. Cho WC, Yip TT, Yip C, Yip V, Thulasiraman V, et al. (2004) Identification of serum amyloid a protein as a potentially useful biomarker to monitor relapse 
Citation: Khadir A, Tiss A (2013) Proteomics Approaches towards Early Detection and Diagnosis of Cancer. J Carcinogene Mutagene S14: 002. doi:10.4172/2157-2518.S14-002

Page 13 of 16

of nasopharyngeal cancer by serum proteomic profiling. Clin Cancer Res 10: 43-52.

86. Cho WC, Yip TT, Ngan RK, Yip TT, Podust VN, et al. (2007) ProteinChip array profiling for identification of disease- and chemotherapy-associated biomarkers of nasopharyngeal carcinoma. Clin Chem 53: 241-250.

87. Jourdain S, Bulman A, Dalmasso E (2010) The Lucid Proteomics System for top-down biomarker research. Arch Physiol Biochem 116: 158-162.

88. Gygi SP, Rist B, Gerber SA, Turecek F, Gelb MH, et al. (1999) Quantitative analysis of complex protein mixtures using isotope-coded affinity tags. Nat Biotechnol 17: 994-999.

89. Ross PL, Huang YN, Marchese JN, Williamson B, Parker K, et al. (2004) Multiplexed protein quantitation in Saccharomyces cerevisiae using aminereactive isobaric tagging reagents. Mol Cell Proteomics 3: 1154-1169.

90. Ong SE, Blagoev B, Kratchmarova I, Kristensen DB, Steen H, et al. (2002) Stable isotope labeling by amino acids in cell culture, SILAC, as a simple and accurate approach to expression proteomics. Mol Cell Proteomics 1: 376-386.

91. Wiese S, Reidegeld KA, Meyer HE, Warscheid B (2007) Protein labeling by iTRAQ: a new tool for quantitative mass spectrometry in proteome research. Proteomics 7: 340-350

92. Mann M (2006) Functional and quantitative proteomics using SILAC. Nat Rev Mol Cell Biol 7: 952-958.

93. Chen R, Yi EC, Donohoe S, Pan S, Eng J, et al. (2005) Pancreatic cancer proteome: the proteins that underlie invasion, metastasis, and immunologic escape. Gastroenterology 129: 1187-1197.

94. Stewart JJ, White JT, Yan X, Collins S, Drescher CW, et al. (2006) Proteins associated with Cisplatin resistance in ovarian cancer cells identified by quantitative proteomic technology and integrated with mRNA expression levels. Mol Cell Proteomics 5: 433-443.

95. Kang UB, Ahn Y, Lee JW, Kim YH, Kim J, et al. (2010) Differential profiling of breast cancer plasma proteome by isotope-coded affinity tagging method reveals biotinidase as a breast cancer biomarker. BMC Cancer 10: 114.

96. Han DK, Eng J, Zhou H, Aebersold R (2001) Quantitative profiling of differentiation-induced microsomal proteins using isotope-coded affinity tags and mass spectrometry. Nat Biotechnol 19: 946-951.

97. Ralhan R, Desouza LV, Matta A, Chandra Tripathi S, Ghanny S, et al. (2008) Discovery and verification of head-and-neck cancer biomarkers by differential protein expression analysis using iTRAQ labeling, multidimensional liquid chromatography, and tandem mass spectrometry. Mol Cell Proteomics 7: 1162-1173.

98. Zhang J, Niu D, Sui J, Ching CB, Chen WN (2009) Protein profile in hepatitis $B$ virus replicating rat primary hepatocytes and HepG2 cells by iTRAQ-coupled 2-D LC-MS/MS analysis: Insights on liver angiogenesis. Proteomics 9: 28362845.

99. Ho J, Kong JW, Choong LY, Loh MC, Toy W, et al. (2009) Novel breast cancer metastasis-associated proteins. J Proteome Res 8: 583-594.

100. Keshamouni VG, Jagtap P, Michailidis G, Strahler JR, Kuick R, et al. (2009) Temporal quantitative proteomics by iTRAQ 2D-LC-MS/MS and corresponding mRNA expression analysis identify post-transcriptional modulation of actincytoskeleton regulators during TGF-beta-Induced epithelial-mesenchymal transition. J Proteome Res 8: 35-47.

101. Li SL, Ye F, Cai WJ, Hu HD, Hu P, et al. (2010) Quantitative proteome analysis of multidrug resistance in human ovarian cancer cell line. J Cell Biochem 109: 625-633.

102. Chenau J, Michelland S, de Fraipont F, Josserand V, Coll JL, et al. (2009) The cell line secretome, a suitable tool for investigating proteins released in vivo by tumors: application to the study of p53-modulated proteins secreted in lung cancer cells. J Proteome Res 8: 4579-4591.

103. Yocum AK, Busch CM, Felix CA, Blair IA (2006) Proteomics-based strategy to identify biomarkers and pharmacological targets in leukemias with $t(4 ; 11)$ translocations. J Proteome Res 5: 2743-2753.

104. Chen N, Sun W, Deng X, Hao Y, Chen X, et al. (2008) Quantitative proteome analysis of HCC cell lines with different metastatic potentials by SILAC. Proteomics 8: 5108-5118.

105. Qu H, Wang Y (2008) Quantitative analysis of surface plasma membrane proteins of primary and metastatic melanoma cells. J Proteome Res 7: 19041915.

106.Xu BJ, Yan W, Jovanovic B, An AQ, Cheng N, et al. (2010) Quantitative analysis of the secretome of TGF-beta signaling-deficient mammary fibroblasts. Proteomics 10: 2458-2470.

107. Geiger T, Cox J, Ostasiewicz P, Wisniewski JR, Mann M (2010) Super-SILAC mix for quantitative proteomics of human tumor tissue. Nat Methods 7: 383 385.

108. Zhang B, VerBerkmoes NC, Langston MA, Uberbacher E, Hettich RL, et al. (2006) Detecting differential and correlated protein expression in label-free shotgun proteomics. J Proteome Res 5: 2909-2918.

109. Liu H, Sadygov RG, Yates JR 3rd (2004) A model for random sampling and estimation of relative protein abundance in shotgun proteomics. Anal Chem 76: 4193-4201.

110. Hu X, Zhang Y, Zhang A, Li Y, Zhu Z, et al. (2009) Comparative serum proteome analysis of human lymph node negative/positive invasive ductal carcinoma of the breast and benign breast disease controls via label-free semi quantitative shotgun technology. OMICS 13: 291-300.

111. Chiou SH, Wu CY (2011) Clinical proteomics: current status, challenges, and future perspectives. Kaohsiung J Med Sci 27: 1-14.

112. Michalski A, Damoc E, Lange O, Denisov E, Nolting D, et al. (2012) Ultra high resolution linear ion trap Orbitrap mass spectrometer (Orbitrap Elite) facilitates top down LC MS/MS and versatile peptide fragmentation modes. Mol Cell Proteomics 11: O111.

113. Bouchal P, Dvorakova M, Scherl A, Garbis SD, Nenutil R, et al. Intact protein profiling in breast cancer biomarker discovery: Protein identification issue and the solutions based on 3D protein separation, bottom-up and top-down mass spectrometry. Proteomics.

114. Schiess R, Wollscheid B, Aebersold R (2009) Targeted proteomic strategy for clinical biomarker discovery. Mol Oncol 3: 33-44.

115. Tiss A, Hasan A, Khadir A, Dehbi M, Dermime S (2013) Innovative Tools for Early Detection of Cancer, in Cancer Biomarkers: Non-Invasive Early Diagnosis and Prognosis. Taylor \& Francis/CRC Press.

116. Kulasingam V, Diamandis EP (2008) Tissue culture-based breast cance biomarker discovery platform. Int J Cancer 123: 2007-2012.

117. Jansen FH, Krijgsveld J, van Rijswijk A, van den Bemd GJ, van den Berg MS, et al. (2009) Exosomal secretion of cytoplasmic prostate cancer xenograftderived proteins. Mol Cell Proteomics 8: 1192-1205.

118. Whiteaker JR, Lin C, Kennedy J, Hou L, Trute M, et al. (2011) A targeted proteomics-based pipeline for verification of biomarkers in plasma. Nat Biotechnol 29: 625-634

119. Addona TA, Shi X, Keshishian H, Mani DR, Burgess M, et al. (2011) A pipeline that integrates the discovery and verification of plasma protein biomarkers reveals candidate markers for cardiovascular disease. Nat Biotechnol 29: 635-643.

120. Johnson SA, Hunter T (2005) Kinomics: methods for deciphering the kinome. Nat Methods 2: 17-25

121. Taylor AD, Hancock WS, Hincapie M, Taniguchi N, Hanash SM (2009) Towards an integrated proteomic and glycomic approach to finding cancer biomarkers. Genome Med 1: 57

122. Zhou H, Watts JD, Aebersold R (2001) A systematic approach to the analysis of protein phosphorylation. Nat Biotechnol 19: 375-378.

123. Whelan SA, Lu M, He J, Yan W, Saxton RE, et al. (2009) Mass spectrometry (LC-MS/MS) site-mapping of $\mathrm{N}$-glycosylated membrane proteins for breast cancer biomarkers. J Proteome Res 8: 4151-4160.

124. Chaerkady R, Thuluvath PJ, Kim MS, Nalli A, Vivekanandan P, et al (2008) O Labeling for a Quantitative Proteomic Analysis of Glycoproteins in Hepatocellular Carcinoma. Clin Proteomics 4: 137-155.

125. Parikh K, Peppelenbosch MP (2010) Kinome profiling of clinical cancer specimens. Cancer Res 70: 2575-2578.

126. Hung KE, Yu KH (2010) Proteomic approaches to cancer biomarkers Gastroenterology 138: 46-51.

127. Chuang HY, Lee E, Liu YT, Lee D, Ideker T (2007) Network-based classification of breast cancer metastasis. Mol Syst Biol 3: 140. 
Citation: Khadir A, Tiss A (2013) Proteomics Approaches towards Early Detection and Diagnosis of Cancer. J Carcinogene Mutagene S14: 002. doi:10.4172/2157-2518.S14-002

Page 14 of 16

128. Auffray C (2007) Protein subnetwork markers improve prediction of cancer outcome. Mol Syst Biol 3: 141

129. Taylor IW, Linding R, Warde-Farley D, Liu Y, Pesquita C, et al. (2009) Dynamic modularity in protein interaction networks predicts breast cancer outcome. Nat Biotechnol 27: 199-204.

130. Latterich M, Schnitzer JE (2011) Streamlining biomarker discovery. Nat Biotechnol 29: 600-602.

131. Picotti P, Aebersold R (2012) Selected reaction monitoring-based proteomics: workflows, potential, pitfalls and future directions. Nat Methods 9: 555-566.

132. Addona TA, Abbatiello SE, Schilling B, Skates SJ, Mani DR, et al. (2009) Multi-site assessment of the precision and reproducibility of multiple reaction monitoring-based measurements of proteins in plasma. Nat Biotechnol 27 633-641.

133. Picotti P, Bodenmiller B, Mueller LN, Domon B, Aebersold R (2009) Full dynamic range proteome analysis of $\mathrm{S}$. cerevisiae by targeted proteomics. Cell 138: 795-806.

134. Kitteringham NR, Jenkins RE, Lane CS, Elliott VL, Park BK (2009) Multiple reaction monitoring for quantitative biomarker analysis in proteomics and metabolomics. J Chromatogr B Analyt Technol Biomed Life Sci 877: 12291239.

135. Selevsek N, Matondo M, Sanchez Carbayo M, Aebersold R, Domon B (2011) Systematic quantification of peptides/proteins in urine using selected reaction monitoring. Proteomics 11: 1135-1147.

136. Caldwell RL, Caprioli RM (2005) Tissue profiling by mass spectrometry: a review of methodology and applications. Mol Cell Proteomics 4: 394-401.

137. Chaurand P, Schwartz SA, Reyzer ML, Caprioli RM (2005) Imaging mass spectrometry: principles and potentials. Toxicol Pathol 33: 92-101.

138. Reyzer ML, Caprioli RM (2005) MALDI mass spectrometry for direct tissue analysis: a new tool for biomarker discovery. J Proteome Res 4: 1138-1142.

139. Bateson H, Saleem S, Loadman PM, Sutton CW (2011) Use of matrixassisted laser desorption/ionisation mass spectrometry in cancer research. $J$ Pharmacol Toxicol Methods 64: 197-206.

140. Franck J, Arafah K, Elayed M, Bonnel D, Vergara D, et al. (2009) MALD imaging mass spectrometry: state of the art technology in clinical proteomics. Mol Cell Proteomics 8: 2023-2033.

141. Gagnon H, Franck J, Wisztorski M, Day R, Fournier I, et al. (2012) Targeted mass spectrometry imaging: specific targeting mass spectrometry imaging technologies from history to perspective. Prog Histochem Cytochem 47: 133174.

142. Bonnel D, Longuespee R, Franck J, Roudbaraki M, Gosset P, et al. (2011) Multivariate analyses for biomarkers hunting and validation through on-tissue bottom-up or in-source decay in MALDI-MSI: application to prostate cancer. Anal Bioanal Chem 401: 149-165.

143. El Ayed M, Bonnel D, Longuespée R, Castelier C, Franck J, et al. (2010) MALDI imaging mass spectrometry in ovarian cancer for tracking, identifying, and validating biomarkers. Med Sci Monit 16: BR233-245.

144. Andersson M, Groseclose MR, Deutch AY, Caprioli RM (2008) Imaging mass spectrometry of proteins and peptides: 3D volume reconstruction. $\mathrm{Nat}$ Methods 5: 101-108.

145. McDonnell LA, Corthals GL, Willems SM, van Remoortere A, van Zeijl RJ, et al. (2010) Peptide and protein imaging mass spectrometry in cancer research. J Proteomics 73: 1921-1944.

146. Day YS, Baird CL, Rich RL, and Myszka DG (2002) Direct comparison of binding equilibrium, thermodynamic, and rate constants determined by surface- and solution-based biophysical methods. Protein Sci 11: 1017-1025.

147.Phillips KS, Cheng Q (2007) Recent advances in surface plasmon resonance based techniques for bioanalysis. Anal Bioanal Chem 387: 1831-1840.

148. Stigter EC, de Jong GJ, van Bennekom WP (2005) An improved coating for the isolation and quantitation of interferon-gamma in spiked plasma using surface plasmon resonance (SPR). Biosens Bioelectron 21: 474-482.

149. Reddy PJ, Sadhu S, Ray S, Srivastava S (2012) Cancer biomarker detection by surface plasmon resonance biosensors. Clin Lab Med 32: 47-72.

150. Remy-Martin F, El Osta M, Lucchi G, Zeggari R, Leblois T, et al. (2012)
Surface plasmon resonance imaging in arrays coupled with mass spectrometry (SUPRA-MS): proof of concept of on-chip characterization of a potential breast cancer marker in human plasma. Anal Bioanal Chem 404: 423-432.

151. Triebel F, Hacene K, Pichon, A soluble lymphocyte activation gene-3 (sLAG3 ) protein as a prognostic factor in human breast cancer expressing estrogen or progesterone receptors. Cancer Lett 235: 147-153.

152. M'Koma AE, Blum DL, Norris JL, Koyama T, Billheimer D, et al. (2007) Detection of pre-neoplastic and neoplastic prostate disease by MALDI profiling of urine. Biochem Biophys Res Commun 353: 829-834.

153. Villanueva J, Shaffer DR, Philip J, Chaparro CA, Erdjument-Bromage $\mathrm{H}$ et al. (2006) Differential exoprotease activities confer tumor-specific serum peptidome patterns. J Clin Invest 116: 271-284.

154. Aresta A, Calvano CD, Palmisano F, Zambonin CG, Monaco A, et al. (2008) Impact of sample preparation in peptide/protein profiling in human serum by MALDI-TOF mass spectrometry. J Pharm Biomed Anal 46: 157-164.

155. de Noo ME, Deelder A, van der Werff M, Ozalp A, Mertens B, et al. (2006) MALDI-TOF serum protein profiling for the detection of breast cancer. Onkologie 29: 501-506.

156. Shin S, Cazares L, Schneider H, Mitchell S, Laronga C, et al. (2007) Serum biomarkers to differentiate benign and malignant mammographic lesions. J Am Coll Surg 204: 1065-1071.

157. Goufman El, Moshkovskii SA, Tikhonova OV, Lokhov PG, Zgoda VG, et al (2006) Two-dimensional electrophoretic proteome study of serum thermostable fraction from patients with various tumor conditions. Biochemistry (Mosc) 71 $354-360$

158. Callesen AK, Mohammed S, Bunkenborg J, Kruse TA, Cold S, et al.(2005) Serum protein profiling by miniaturized solid-phase extraction and matrixassisted laser desorption/ionization mass spectrometry. Rapid Commun Mass Spectrom 19: 1578-1586.

159. Alexander H, Stegner AL, Wagner-Mann C, Du Bois GC, Alexander S, et al. (2004) Proteomic analysis to identify breast cancer biomarkers in nipple aspirate fluid. Clin Cancer Res 10: 7500-7510.

160. Dekker LJ, Boogerd W, Stockhammer G, Dalebout JC, Siccama I, et al. (2005) MALDI-TOF mass spectrometry analysis of cerebrospinal fluid tryptic peptide profiles to diagnose leptomeningeal metastases in patients with breast cancer. Mol Cell Proteomics 4: 1341-1349.

161. Ward DG, Roberts K, Brookes MJ, Joy H, Martin A, et al. (2008) Increased hepcidin expression in colorectal carcinogenesis. World J Gastroenterol 14 $1339-1345$

162. de Noo ME, Mertens BJ, Ozalp A, Bladergroen MR, van der Werff MP, et al. (2006) Detection of colorectal cancer using MALDI-TOF serum protein profiling. Eur J Cancer 42: 1068-1076.

163. Hu S, Yu T, Xie Y, Yang Y, Li Y, et al. (2007) Discovery of oral fluid biomarkers for human oral cancer by mass spectrometry. Cancer Genomics Proteomics 4: $55-64$.

164. Cheng AJ, Chen LC, Chien KY, Chen YJ, Chang JT, et al. (2005) Ora cancer plasma tumor marker identified with bead-based affinity-fractionated proteomic technology. Clin Chem 51: 2236-2244.

165. Chang JT, Chen LC, Wei SY, Chen YJ, Wang HM, et al. (2006) Increase diagnostic efficacy by combined use of fingerprint markers in mass spectrometry--plasma peptidomes from nasopharyngeal cancer patients for example. Clin Biochem 39: 1144-1151.

166. Ebert MP, Meuer J, Wiemer JC, Schulz HU, Reymond MA, et al. (2004) Identification of gastric cancer patients by serum protein profiling. J Proteome Res 3: 1261-1266.

167. Gericke B, Raila J, Sehouli J, Haebel S, Könsgen D, et al. (2005) Microheterogeneity of transthyretin in serum and ascitic fluid of ovarian cancer patients. BMC Cancer 5: 133.

168. Liu C, Shea N, Rucker S, Harvey L, Russo P, et al. (2007) Proteomic patterns for classification of ovarian cancer and CTCL serum samples utilizing peak pairs indicative of post-translational modifications. Proteomics 7: 4045-4052.

169. Lopez MF, Mikulskis A, Kuzdzal S, Golenko E, Petricoin EF 3rd, et al (2007) A novel, high-throughput workflow for discovery and identification of serum carrier protein-bound peptide biomarker candidates in ovarian cance samples. Clin Chem 53: 1067-1074. 
Citation: Khadir A, Tiss A (2013) Proteomics Approaches towards Early Detection and Diagnosis of Cancer. J Carcinogene Mutagene S14: 002. doi:10.4172/2157-2518.S14-002

170. Semmes OJ, Feng Z, Adam BL, Banez LL, Bigbee WL, et al. (2005) Evaluation of serum protein profiling by surface-enhanced laser desorption/ionization time-of-flight mass spectrometry for the detection of prostate cancer: I. Assessment of platform reproducibility. Clin Chem 51: 102-112.

171. Adam, BL, Qu Y, Davis JW, Ward MD, Clements MA, et al. (2002) Serum protein fingerprinting coupled with a pattern-matching algorithm distinguishes prostate cancer from benign prostate hyperplasia and healthy men. Cancer Res 62: 3609-3614.

172. Petricoin EF 3rd, Ornstein DK, Paweletz CP, Ardekani A, Hackett PS, et al. (2002) Serum proteomic patterns for detection of prostate cancer. J Natl Cancer Inst 94: 1576-1578.

173. Streckfus CF, Bigler LR, Zwick M (2006) The use of surface-enhanced laser desorption/ionization time-of-flight mass spectrometry to detect putative breas cancer markers in saliva: a feasibility study. J Oral Pathol Med 35: 292-300.

174.Li J, Zhang Z, Rosenzweig J, Wang YY, Chan DW (2002) Proteomics and bioinformatics approaches for identification of serum biomarkers to detect breast cancer. Clin Chem 48: 1296-1304.

175. Callesen AK, Vach W, Jørgensen PE, Cold S, Tan Q, et al. (2008) Combined experimental and statistical strategy for mass spectrometry based serum protein profiling for diagnosis of breast cancer: a case-control study. J Proteome Res 7: 1419-1426.

176. Mathelin C, Cromer A, Wendling C, Tomasetto C, Rio MC (2006) Serum biomarkers for detection of breast cancers: A prospective study. Breast Cancer Res Treat 96: 83-90.

177. Ricolleau, G, Charbonnel C, Lode L, Loussouarn D, Joalland MP, et al. (2006) Surface-enhanced laser desorption/ionization time of flight mass spectrometry protein profiling identifies ubiquitin and ferritin light chain as prognostic biomarkers in node-negative breast cancer tumors. Proteomics 6: 1963-1975

178. van Winden AW, Gast MC, Beijnen JH, Rutgers EJ, Grobbee DE, et al. (2009) Validation of previously identified serum biomarkers for breast cancer with SELDI-TOF MS: a case control study. BMC Med Genomics 2: 4.

179. Opstal-van Winden AW, Krop EJ, Kåredal MH, Gast MC, Lindh $\mathrm{CH}$, et al. (2011) Searching for early breast cancer biomarkers by serum protein profiling of pre-diagnostic serum; a nested case-control study. BMC Cancer 11: 381.

180. Gast MC, van Dulken EJ, van Loenen TK, Kingma-Vegter F, Westerga J, et al. (2009) Detection of breast cancer by surface-enhanced laser desorption/ ionization time-of-flight mass spectrometry tissue and serum protein profiling. Int J Biol Markers 24: 130-141.

181. Caputo E, Lombardi ML, Luongo V, Moharram R, Tornatore P, et al. (2005) Peptide profiling in epithelial tumor plasma by the emerging proteomic techniques. J Chromatogr B Analyt Technol Biomed Life Sci 819: 59-66.

182. Mendrinos S, Nolen JD, Styblo T, Carlson G, Pohl J, et al. (2005) Cytologic findings and protein expression profiles associated with ductal carcinoma of the breast in ductal lavage specimens using surface-enhanced laser desorption and ionization-time of flight mass spectrometry. Cancer 105: 178-183.

183. Paweletz CP, Trock B, Pennanen M, Tsangaris T, Magnant C, et al. (2001) Proteomic patterns of nipple aspirate fluids obtained by SELDI-TOF: potentia for new biomarkers to aid in the diagnosis of breast cancer. Dis Markers 17: 301-307.

184.Sauter ER, Shan S, Hewett JE, Speckman P, Du Bois GC (2005) Proteomic analysis of nipple aspirate fluid using SELDI-TOF-MS. Int J Cancer 114: 791 796.

185. Sauter ER, Zhu W, Fan XJ, Wassell RP, Chervoneva I, et al. (2002) Proteomic analysis of nipple aspirate fluid to detect biologic markers of breast cancer. $\mathrm{Br}$ J Cancer 86: 1440-1443.

186. Fowler LJ, Lovell MO, Izbicka E (2004) Fine-needle aspiration in PreservCyt: a novel and reproducible method for possible ancillary proteomic pattern expression of breast neoplasms by SELDI-TOF. Mod Pathol 17: 1012-1020.

187. Coombes KR, Fritsche HA Jr, Clarke C, Chen JN, Baggerly KA, et al. (2003) Quality control and peak finding for proteomics data collected from nipple aspirate fluid by surface-enhanced laser desorption and ionization. Clin Chem 49: 1615-1623.

188. Li J, Zhao J, Yu X, Lange J, Kuerer H, et al. (2005) Identification of biomarkers for breast cancer in nipple aspiration and ductal lavage fluid. Clin Cancer Res 11: 8312-8320.

189. Pawlik TM, Fritsche H, Coombes KR, Xiao L, Krishnamurthy S, et al. (2005)
Significant differences in nipple aspirate fluid protein expression between healthy women and those with breast cancer demonstrated by time-of-flight mass spectrometry. Breast Cancer Res Treat 89: 149-157.

190. Kuerer HM, Coombes KR, Chen JN, Xiao L, Clarke C, et al. (2004) Association between ductal fluid proteomic expression profiles and the presence of lymph node metastases in women with breast cancer. Surgery 136: 1061-1069.

191.Traub F, Feist H, Kreipe HH, Pich A (2005) SELDI-MS-based expression profiling of ductal invasive and lobular invasive human breast carcinomas. Pathol Res Pract 201: 763-770.

192. Noble JL, Dua RS, Coulton GR, Isacke CM, Gui GP (2007) A comparative proteinomic analysis of nipple aspiration fluid from healthy women and women with breast cancer. Eur J Cancer 43: 2315-2320.

193. Engwegen, JY, Helgason HH, Cats A, Harris N, Bonfrer JM, et al. (2006) Identification of serum proteins discriminating colorectal cancer patients and healthy controls using surface-enhanced laser desorption ionisation-time of flight mass spectrometry. World J Gastroenterol 12: 1536-1544.

194. Ward DG, Suggett N, Cheng Y, Wei W, Johnson H, et al. (2006) Identification of serum biomarkers for colon cancer by proteomic analysis. $\mathrm{Br} \mathrm{J}$ Cancer 94 1898-1905.

195. Ren H, Du N, Liu G, Hu HT, Tian W, et al. (2006) Analysis of variabilities of serum proteomic spectra in patients with gastric cancer before and after operation. World J Gastroenterol 12: 2789-2792.

196. Ye B, Skates S, Mok SC, Horick NK, Rosenberg HF, et al. (2006) Proteomicbased discovery and characterization of glycosylated eosinophil-derived neurotoxin and $\mathrm{COOH}$-terminal osteopontin fragments for ovarian cancer in urine. Clin Cancer Res 12: 432-441.

197. Ye B, Cramer DW, Skates SJ, Gygi SP, Pratomo V, et al. (2003) Haptoglobinalpha subunit as potential serum biomarker in ovarian cancer: identification and characterization using proteomic profiling and mass spectrometry. Clin Cancer Res 9: 2904-2911.

198.Zhang Z, Bast RC Jr, Yu Y, Li J, Sokoll LJ, et al. (2004) Three biomarkers identified from serum proteomic analysis for the detection of early stage ovarian cancer. Cancer Res 64: 5882-5890.

199. Helleman J, van der Vlies D, Jansen MP, Luider TM, van der Burg ME, et al. (2008) Serum proteomic patterns for ovarian cancer monitoring. Int J Gynecol Cancer 18: 985-995.

200. Kozak KR, Amneus MW, Pusey SM, Su F, Luong MN, et al. (2003) Identification of biomarkers for ovarian cancer using strong anion-exchange ProteinChips: potential use in diagnosis and prognosis. Proc Natl Acad Sci U S A 100: 12343-12348.

201.Zhang H, Kong B, Qu X, Jia L, Deng B, et al. (2006) Biomarker discovery for ovarian cancer using SELDI-TOF-MS. Gynecol Oncol 102: 61-66.

202. Conrads TP, Fusaro VA, Ross S, Johann D, Rajapakse V, et al. (2004) Highresolution serum proteomic features for ovarian cancer detection. Endocr Relat Cancer 11: 163-178.

203. Wu SP, Lin YW, Lai HC, Chu TY, Kuo YL, et al. (2006) SELDI-TOF MS profiling of plasma proteins in ovarian cancer. Taiwan J Obstet Gynecol 45: 26-32.

204. Moshkovskii SA, Serebryakova MV, Kuteykin-Teplyakov KB, Tikhonova OV Goufman El, et al. (2005) Ovarian cancer marker of $11.7 \mathrm{kDa}$ detected by proteomics is a serum amyloid A1. Proteomics 5: 3790-3797.

205. Lin YW, Lai HC, Lin CY, Chiou JY, Shui HA, et al. (2006) Plasma proteomic profiling for detecting and differentiating in situ and invasive carcinomas of the uterine cervix. Int J Gynecol Cancer 16: 1216-1224.

206. Munro NP, Cairns DA, Clarke P, Rogers M, Stanley AJ, et al. (2006) Urinary biomarker profiling in transitional cell carcinoma. Int J Cancer 119: 2642-2650.

207. Rogers MA, Clarke P, Noble J, Munro NP, Paul A, et al. (2003) Proteomic profiling of urinary proteins in renal cancer by surface enhanced laser desorption ionization and neural-network analysis: identification of key issues affecting potential clinical utility. Cancer Res 63: 6971-683.

208. Tolson J, Bogumil R, Brunst E, Beck H, Elsner R, et al. (2004) Serum protein profiling by SELDI mass spectrometry: detection of multiple variants of serum amyloid alpha in renal cancer patients. Lab Invest 84: 845-856.

209. David N, Duyne R, Bingham J (2008) Localized surface plasmon resonance nanobiosensors for the detection of a prostate cancer biomarker. Nanoscape 5: 14-19. 
Citation: Khadir A, Tiss A (2013) Proteomics Approaches towards Early Detection and Diagnosis of Cancer. J Carcinogene Mutagene S14: 002. doi:10.4172/2157-2518.S14-002

210. Kang DY, Lee JH, Oh BK, Choi JW (2009) Ultra-sensitive immunosensor for beta-amyloid (1-42) using scanning tunneling microscopy-based electrical detection. Biosens Bioelectron 24: 1431-1436.

211. Krishnan S, Mani V, Wasalathanthri D, Kumar CV, Rusling JF (2011) Attomolar detection of a cancer biomarker protein in serum by surface plasmon resonance using superparamagnetic particle labels. Angew Chem Int Ed Engl 50: 1175-1178.

212. Cao C, Kim JP, Kim BW, Chae H, Yoon HC, et al. (2006) A strategy for sensitivity and specificity enhancements in prostate specific antigen-alpha1antichymotrypsin detection based on surface plasmon resonance. Biosens Bioelectron 21: 2106-2113.

213. Jang, H., K. Park, and C. Kang (2009) Optical fiber SPR biosensor with sandwich assay for the detection of prostate specific antigen. Optics Comm 28: 2827-2830.

214. Malic L, Sandros MG, Tabrizian M (2011) Designed biointerface using nearinfrared quantum dots for ultrasensitive surface plasmon resonance imaging biosensors. Anal Chem 83: 5222-5229.

215. Carrascosa LG, Calle A, Lechuga LM (2009) Label-free detection of DNA mutations by SPR: application to the early detection of inherited breast cancer. Anal Bioanal Chem 393: 1173-1182.

216. Chang CC, Chiu NF, Lin DS, Chu-Su Y, Liang YH, et al. (2010) High-sensitivity detection of carbohydrate antigen 15-3 using a gold/zinc oxide thin film surface plasmon resonance-based biosensor. Anal Chem 82: 1207-1212.

217. Singh AK, Kant S, Parshad R, Banerjee N, Dey S (2011) Evaluation of human LOX-12 as a serum marker for breast cancer. Biochem Biophys Res Commun 414: $304-308$

218. Myung JH, Launiere CA, Eddington DT, Hong S (2010) Enhanced tumor cell isolation by a biomimetic combination of E-selectin and anti-EpCAM: implications for the effective separation of circulating tumor cells (CTCs). Langmuir 26: 8589-8596.

219. Ladd J, Lu H, Taylor AD, Goodell V, Disis ML, et al. (2009) Direct detection of carcinoembryonic antigen autoantibodies in clinical human serum samples using a surface plasmon resonance sensor. Colloids Surf B Biointerfaces 70: $1-6$.
220.Su F, Xu C, and Taya M (2008) Detection of carcinoembryonic antigens using a surface plasmon resonance biosensor. Sensors Actuators 8: 4282-4295.

221. Li Y, Lee HJ, Corn RM (2007) Detection of protein biomarkers using RNA aptamer microarrays and enzymatically amplified surface plasmon resonance imaging. Anal Chem 79: 1082-1088.

222. Ladd J, Taylor AD, Piliarik M, Homola J, Jiang S (2009) Label-free detection of cancer biomarker candidates using surface plasmon resonance imaging. Anal Bioanal Chem 393: 1157-1163.

223. Kapoor V, Singh AK, Dey S, Sharma SC, Das SN (2010) Circulating cycloxygenase-2 in patients with tobacco-related intraoral squamous cel carcinoma and evaluation of its peptide inhibitors as potential antitumor agent J Cancer Res Clin Oncol 136: 1795-1804.

224. Yang CY, Brooks E, Li Y, Denny P, Ho CM, et al. (2005) Detection of picomola levels of interleukin-8 in human saliva by SPR. Lab Chip 5: 1017-1023.

225. Piliarik M, Bocková M, Homola J (2010) Surface plasmon resonance biosensor for parallelized detection of protein biomarkers in diluted blood plasma. Biosens Bioelectron 26: 1656-1661.

226. Vaisocherová H, Faca VM, Taylor AD, Hanash S, Jiang S (2009) Comparative study of SPR and ELISA methods based on analysis of CD166/ALCAM levels in cancer and control human sera. Biosens Bioelectron 24: 2143-2148.

227. Fang X, Tie J, Xie Y, Li Q, Zhao Q, et al. (2010) Detection of gastric carcinomaassociated antigen MG7-Ag in human sera using surface plasmon resonance sensor. Cancer Epidemiol 34: 648-651.

228. Teramura Y, Iwata H (2007) Label-free immunosensing for alpha-fetoprotein in human plasma using surface plasmon resonance. Anal Biochem 365: $201-$ 207.

229. Mie M, Kai T, Le T, Cass AE, Kobatake E (2013) Selection of DNA aptamers with affinity for pro-gastrin-releasing peptide (proGRP), a tumor marker for small cell lung cancer. Appl Biochem Biotechnol 169: 250-255.

230. Yuan J, Duan R, Yang H, Luo X, Xi M (2012) Detection of serum human epididymis secretory protein 4 in patients with ovarian cancer using a label-free biosensor based on localized surface plasmon resonance. Int J Nanomedicine 7: 2921-2928.

This article was originally published in a special issue, Cancer Diagnosis,

Treatment and Therapy handled by Editor(s). Dr. Said Dermime, King

Fahad Specialist Hospital Dammam, Saudi Arabia 